\title{
A major reorganization of Asian climate by the early Miocene
}

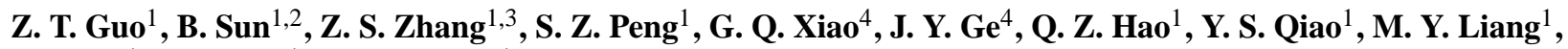 \\ J. F. Liu ${ }^{1}$, Q. Z. Yin ${ }^{1}$, and J. J. Wei ${ }^{1}$ \\ ${ }^{1}$ Key Laboratory of Cenozoic Geology and Environment, Institute of Geology and Geophysics, Chinese Academy of \\ Sciences, P.O. Box 9825, Beijing, 100029, China \\ ${ }^{2}$ Shandong Institute and Laboratory of Geological Sciences, Jinan, 250013, China \\ ${ }^{3}$ Nansen-Zhu International Research Center, Institute of Atmospheric Physics, Chinese Academy of Sciences, Beijing, \\ 100029, China \\ ${ }^{4}$ State Key Laboratory of Loess and Quaternary Geology, Institute of Earth Environment, Chinese Academy of Sciences, P.O. \\ Box 17, Xian, 710075, China
}

Received: 3 April 2008 - Published in Clim. Past Discuss.: 8 May 2008

Revised: 29 July 2008 - Accepted: 29 July 2008 - Published: 18 August 2008

\begin{abstract}
The global climate system experienced a series of drastic changes during the Cenozoic. In Asia, these include the climate transformation from a zonal pattern to a monsoon-dominated pattern, the disappearance of typical subtropical aridity, and the onset of inland deserts. Despite major advances in the last two decades in characterizing and understanding these climate phenomena, disagreements persist relative to the timing, behaviors and underlying causes.

This paper addresses these issues mainly based on two lines of evidence. First, we compiled newly collected data from geological indicators of the Cenozoic environment in China as paleoenvironmental maps of ten intervals. In confirming the earlier observation that a zonal climate pattern was transformed into a monsoonal one, the maps within the Miocene indicate that this change was achieved by the early Miocene, roughly consistent with the onset of loess deposition in China. Although a monsoon-like regime would have existed in the Eocene, it was restricted to tropical-subtropical regions. The latitudinal oscillations of the climate zones during the Paleogene are likely attributable to the imbalance in evolution of polar ice-sheets between the two hemispheres.

Secondly, we examine the relevant depositional and soil forming processes of the Miocene loess-soil sequences to determine the circulation characteristics with emphasis on the early Miocene. Continuous eolian deposition in the middle reaches of the Yellow River since the early Miocene firmly indicates the formation of inland deserts, which have been constantly maintained during the past $22 \mathrm{Ma}$. Grain-
\end{abstract}

size gradients between loess sections indicate northerly dustcarrying winds from northern sources, a clear indication of an Asian winter monsoon system. Meanwhile, welldeveloped Luvisols show evidence that moisture from the oceans reached northern China. This evidence shows the coexistence of two kinds of circulations, one from the ocean carrying moisture and another from the inland deserts transporting dust. The formation of the early Miocene paleosols resulted from interactive soil forming and dust deposition processes in these two seasonally alternating monsoonal circulations. The much stronger development of the early Miocene soils compared to those in the Quaternary loess indicates that summer monsoons were either significantly stronger, more persistent through the year, or both.

These lines of evidence indicate a joint change in circulation and inland aridity by the early Miocene and suggest a dynamic linkage of them. Our recent sensitivity tests with a general circulation model, along with relevant geological data, suggest that the onset of these contrasting wet/dry responses, as well as the change from the "planetary" subtropical aridity pattern to the 'inland' aridity pattern, resulted from the combined effects of Tibetan uplift and withdrawal of the Paratethys seaway in central Asia, as suggested by earlier experiments. The spreading of South China Sea also helped to enhance the south-north contrast of humidity. The Miocene loess record provides a vital insight that these tectonic factors had evolved by the early Miocene to a threshold sufficient to cause this major climate reorganization in Asia.

Correspondence to: $\mathrm{Z}$. T. Guo

(ztguo@mail.iggcas.ac.cn)

Published by Copernicus Publications on behalf of the European Geosciences Union. 

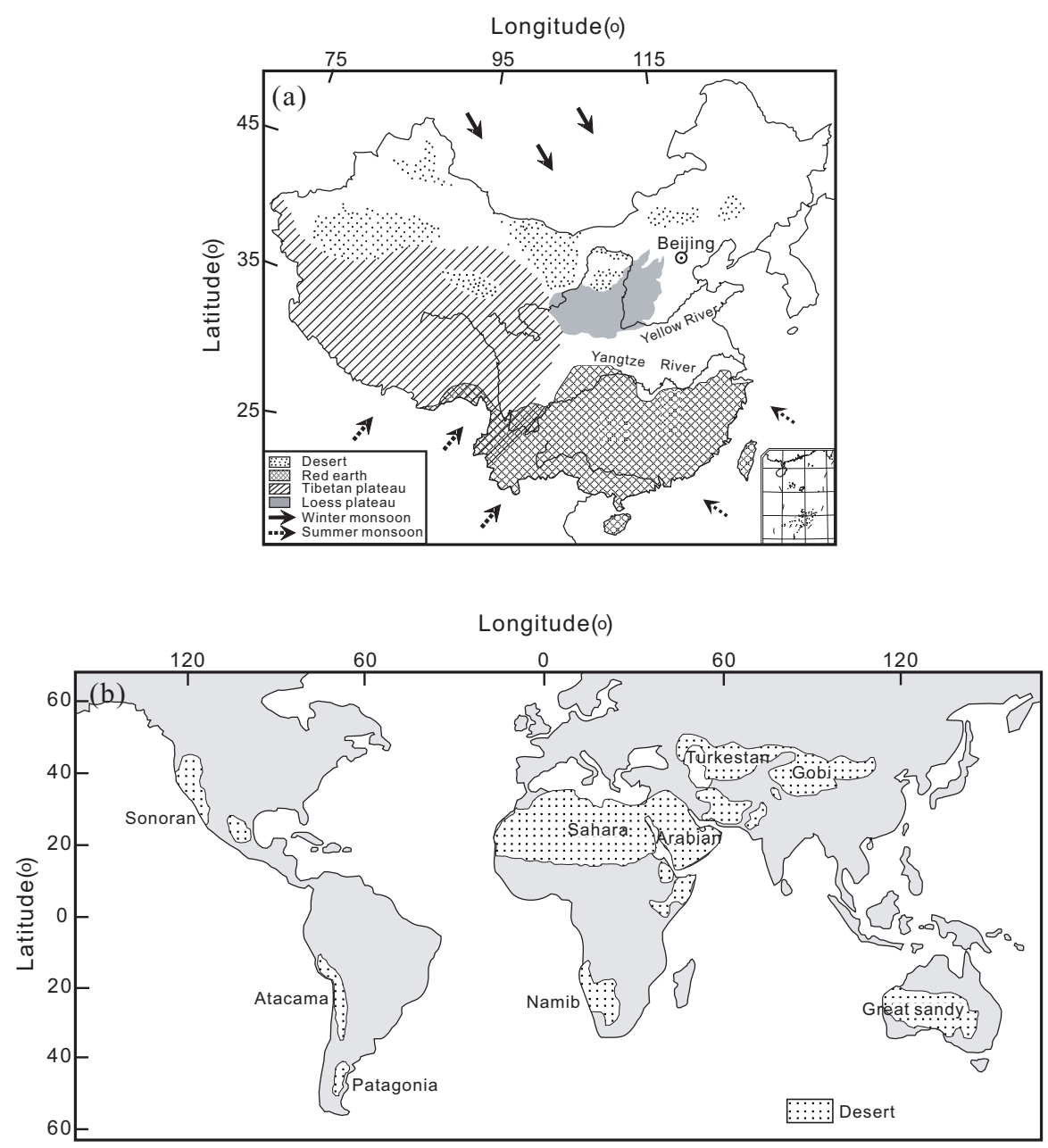

Fig. 1. Sketch maps showing the modern environmental patterns of China and the world. (a) Modern environmental pattern in China and the prevailing atmospheric circulations. The Loess Plateau is located in the middle reaches of the Yellow River, with the Tibetan Plateau to the Southwest, inland deserts to the North and Northwest. The subtropical and tropical regions in southern China are covered by so-called red earth (mainly soils formed under tropical and subtropical humid conditions). Dotted arrows indicate the southwest and southeast Asian summer monsoons, solid arrows indicate the Asian winter monsoon. (b) Distribution of the world drylands (modified after Meigs, 1953). Most of the subtropical zones are occupied by drylands with the exception of East Asia.

\section{Introduction}

The modern environment in Asia is characterized by two prominent features: the moist southern part under the influence of the southwest (South Asian) and southeast (East Asian) summer monsoons, the drylands in the central part beyond the monsoon influence (Wang, 2006). These are clearly illustrated by the climate pattern in China (Fig. 1a). In summer, the fronts of the summer monsoons penetrate northwards into China and lead to abundant rainfall and high temperature. In winter, the region is mainly controlled by the northwesterly dry-cold winds, i.e. the Asia winter monsoon related to the Siberian high-pressure cell (Chen et al., 1991). Currently, precipitation in northern China is mostly brought by the southeast summer monsoon (Chen et al., 1991; Fu,
2003). Although modern observations also indicate a contribution of the southwest summer monsoon to the precipitation in northern China (Chen et al., 1991; Wang, 2006), the effect is largely reduced by the barrier effect of the HimalayanTibetan complex. During the late Cenozoic, a large amount of eolian dust was transported from the inland deserts by winter monsoon winds to the middle reaches of the Yellow River, leading to the formation of the Loess Plateau (Liu, 1985; An et al., 1990; Ding et al., 1995; Liu and Ding, 1998; Guo et al., 2002). The western part of China is also influenced by the westerlies of the Northern Hemisphere (Wang, 2006), but their contribution to regional rainfall is relatively small because of the long continental trajectory. 


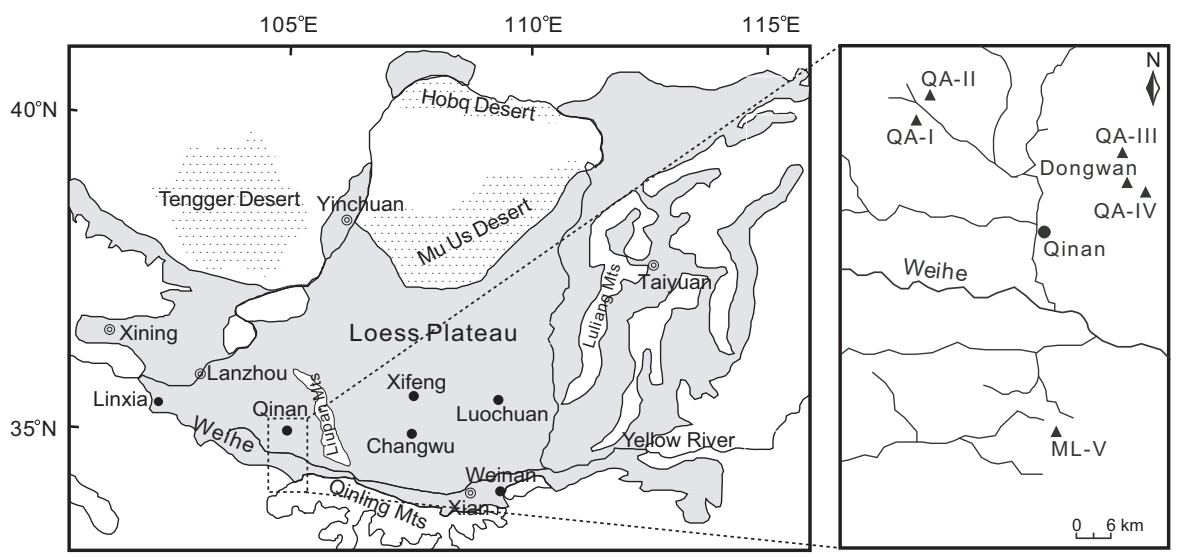

Fig. 2. The Loess Plateau in northern China relative to the inland deserts in northwestern China and various loess sites. The Plateau is delimited by the Liupan Mountains into the eastern and western parts. The right panel corresponds to an expanded part of the western Loess Plateau where the Miocene eolian deposits have been studied.

The very moist conditions in the subtropical zone in Asia, along with the presence of mid-latitude drylands, referred to here as the monsoon-dominated pattern (Guo, 2003), are somewhat unusual compared to the widespread drylands in most subtropical regions (Fig. 1b). These include the Australian and South American deserts in the Southern Hemisphere and the Sahara-Arabian deserts in the Northern Hemisphere. The causes of aridity for these two kinds of deserts are also very different. Except for the North American deserts that are primarily the result of rain-shadow development in the lee of mountains (Kutzbach et al., 1989), most low-latitude aridity results from subtropical high-pressure zones related to the descending branches of the Hadley Cells near the equator and the Ferrell Cells at mid-latitudes over both the hemispheres (Houghton, 1984). The subsiding air of the subtropical highs adiabatically warms, causes the air to dry out, and inhibit condensation, leading to dry conditions on the underlying continents.

In contrast, aridity in Central and East Asia is essentially independent of the subtropical highs, and mainly related to the barrier and thermo-dynamic effects of the HimalayanTibetan complex, the Siberian high-pressure cell and the remote distance from the oceans (Kutzbach et al., 1989, 1993; Ruddiman and Kutzbach, 1989; Chen et al., 1991; Wang et al., 2006). Consequently, we discriminate between these two kinds of drylands as planetary and inland deserts. Because subtropical high-pressure zones are a component of the planetary circulation system mainly forced by solar heating (Houghton, 1984), we assume that they can be traced back to much earlier in Earth history. Consequently, the onset of planetary drylands should be primarily dependent on the timing when a continent drifted to subtropical latitudes.

On the contrary, the onset of inland-type deserts and monsoon-dominated climate in Asia is one of the most prominent changes in the climate system of the Cenozoic
Era (Ruddiman and Kutzbach, 1989). Since the late 1970's, many numerical experiments have been conducted to address their causes. Invoked factors have focused on Tibetan uplift and changes in land-sea distribution (Manabe and Terpstra, 1974; Ruddiman and Kutzbach, 1989; Ruddiman et al., 1989; Kutzbach et al., 1989; 1993; Prell and Kutzbach, 1992; Ramstein et al., 1997; Fluteau et al., 1999; Abe et al., 2003; Zhang et al., 2007a, b).

Meanwhile, studies of geological records have led to major advances about the timing of these changes. On the southern side of the Himalayas, a record of planktonic foraminifera from the Arabian Sea that revealed strong upwelling since the late Miocene at $\sim 8 \mathrm{Ma}$ was interpreted as an indication of the onset or strengthening of the Indian Ocean (South Asian) monsoon (Kroon et al., 1991). The expansion of plants that use $\mathrm{C} 4$ photosynthesis at $\sim 8 \mathrm{Ma}$ in South Asia may also be indicative of strengthening of South Asian monsoon (Quade et al., 1989).

On the northern side of the Himalayan-Tibetan complex, examination on the spatial distribution of geological indicators in China revealed a transformation of the dry areas in the Cenozoic from a roughly W-E zonal belt across China to a region restricted to northwestern China (Wang, 1990). Later, six paleoenvironmental maps corresponding to the Paleocene, Eocene, Oligocene, Miocene, late Miocene-early Pliocene and Pliocene were compiled based on various geological and biological indicators (Liu and Guo, 1997). The results showed a roughly zonal climate pattern from the $\mathrm{Pa}$ leocene to Oligocene, followed by a pattern similar to the present-day for later epochs, suggesting that the reorganization occurred during the Oligocene or Miocene. Broadly similar results have been given by a detailed compilation of paleobotanical evidence (Sun and Wang, 2005). Geological sequences from northern China also revealed more accurate age control on these changes. A pollen record from 
the Linxia basin showed a significant increase in the contents of tree pollen, which was interpreted as an indication of the onset of Asian monsoon (Shi et al., 1999).

Recently, study of loess-soil sequences of Miocene ages (Guo et al., 2002) indicated that sizeable deserts in the Asian inlands and a monsoonal pattern had both been established by $22 \mathrm{Ma}$ ago in the Loess Plateau region of eastern Asia. Correlative sequences with high-resolution magnetostratigraphic time control show layered sequences of fully developed soils indicative of south-to-north inflow typical of wet summer monsoons, alternating with loess layers indicative of stronger north-to-south outflow in dry winter monsoons. These alternations attest to cyclical changes of the summer and winter monsoons at the orbital scale (Guo et al., 2002).

Despite these major advances, a number of questions remain to be addressed.

1. Previous paleoenvironmental maps were mainly compiled in intervals of epochs, and hence have rather long time coverage (Liu and Guo, 1997; Sun and Wang, 2005). Because dominant views about the timing of monsoon climate in Asia focused on the late Miocene (Quade et al., 1989; Kroon et al., 1991) or around the Oligocene-Miocene boundary (Liu and Guo, 1997; Sun and Wang, 2005), a more detailed examination on the climate patterns within the Oligocene and Miocene would provide helpful insights about the timing of pattern changes. Over the past ten years, a significant amount of new geological information has been acquired, providing the opportunity to reexamine the spatial patterns in greater detail. Although the climates in Asia in the Paleocene, Eocene and Oligocene are commonly characterized by zonal patterns (Liu and Guo, 1997; Sun and Wang, 2005), their link to Cenozoic global ice-volume and temperature changes as documented by marine $\delta^{18} \mathrm{O}$ records (Zachos et al., 2001) also needs to be discussed.

2. Examination of temporal and spatial variations of the Quaternary and Pliocene eolian deposits have provided a significant amount of information on monsoon and dryland evolution in Asia during the past $8 \mathrm{Ma}$ (e.g. Liu and Ding, 1998; Miao et al., 2004). Their distribution in the Miocene remains unclear because of the insufficient number of Miocene loess sections. Recently, several new sections at different localities have been dated and analyzed. These sections provide an opportunity to further examine climate features prior to $8 \mathrm{Ma}$. Moreover, specific features of monsoonal loesssoil sequences in China can be compared to those in non-monsoon zones such as Europe and North America (Rousseau and Kukla, 1994; Rousseau et al., 1998; Berger, 2003).
In Sect. 2 of this paper, we summarize Cenozoic changes of climate patterns using paleoenvironmental maps of ten time intervals based on new collection and re-examination of geological indicators from the literature. In Sect. 3, we address the implications of the Miocene eolian deposits in northern China regarding the early stage of Asian inland desertification and monsoon climate. Other relevant geological records are reviewed in Sect. 4. In Sect. 5, we discuss the potential causes of this major change of Asian climate based on the insights from the Miocene loess-soil sequences, the available numerical experiments and tectonic studies.

\section{Cenozoic climate patterns in Asia}

The data used to compile the paleoenvironmental maps were acquired mainly for studies of stratigraphy, paleontology, paleogeography and paleoclimate, for resource exploration and for geological mapping. The main sources are listed in the Supplementary Material http://www.clim-past.net/4/153/ 2008/cp-4-153-2008-supplement.pdf. Among a larger number of collected records, we have selected 385 for compiling the paleoenvironment maps based on reliability of chronology and clarity of environmental significance. The chronologies of 157 records are based on mammalian fossils, those of 146 records on pollen chronology, and those of 44 records on other biochronological indicators (for example foraminifera, ostracoda). Isotope or magnetostratigraphic ages are available for 38 records.

In China, calibrations of fossil chronology by isotopic and geomagnetic dating are only available for scattered sites. Most investigations used relative chronology assignments, which potentially have large uncertainties. We infer a potential uncertainty of at least several million years for data without isotopic and geomagnetic age controls even with careful selection and examination.

These indicators are classified into three groups (humid, semi-arid and arid) according to their environmental implications. Indicators of humid conditions include coal, pollen and fossil assemblages typical of forest conditions. Arid indicators include saline and alkaline lake deposits, as well as pollen and fossils typical of deserts and desert-steppe environments. Pedogenic carbonates, pollen and fossil assemblages typical of sparse forest-steppe and steppe are used as indicators of semi-arid environments. Because of the potential uncertainty of environmental significance for some mammalian fossils, only carefully studied fauna with modern analogues are used for compiling the maps although most faunal data are useful for chronology. The maps compiled for the ten different intervals are shown in Figs. 3 and 4. The data used in each map are listed in the Supplementary Material. 


\subsection{Paleogene climate patterns}

The Paleocene data are rather sparse, probably due to tectonic changes and erosion, but they are abundant enough to show the dominance of arid and semi-arid conditions in large areas of China. Their spatial distribution defines a broad, roughly W-E dry belt across the country (Fig. 3a). Only the southern-most Hainan Islands and northeastern China were dominated by more humid conditions. The Eocene data are significantly more abundant, showing a pattern essentially similar to that of the Paleocene (Fig. 3b). However, a northwards migration of the southern boundary of the dry belt is evident. A further slight northwards retreat of this boundary is observed for the Oligocene, although the basic environmental pattern remained zonal (Fig. 3c).

We further subdivided the Oligocene data into two groups, one corresponding to the early and mid-Oligocene (Fig. 3d), and the other to the late Oligocene (Fig. 3e). The data are sufficient to show a zonal climate pattern for the early and midOligocene, but the pattern for the late Oligocene is hard to define because of a lack of data in southern China, probably due to tectonic movements and large-scale erosion (Zhang and Guo, 2005). In any case, the map for the late Oligocene does not clearly show a pattern different from that of the early and mid-Oligocene.

These five maps show that climate in Asia during most of the Paleogene was characterized by roughly W-E zonal patterns with dry conditions in southern China where humid conditions prevail today (Fig. 1a). A dry belt existed from the western-most part to the eastern coasts at latitudes similar to the present-day drylands in North Africa (Fig. 1b). The aridity was presumably caused by the subtropical high-pressure zone of the Northern Hemisphere, because of the lack of evidence of mountain ranges (and rain shadows) for the Paleogene. Thus, the zonal climate pattern is largely attributable to a planetary circulation system (Liu and Guo, 1997; Sun and Wang, 2005), rather than a monsoon-dominated regime.

The broad dry zone with a northern boundary at higher latitudes has no modern analog, probably for two main reasons. First, the climate zones within each mapping interval would have experienced significant short-term latitudinal oscillations caused by changes in global boundary conditions, leading to a broader distribution of the arid indicators. This possibility is supported by the scattered humid indicators within the dry belt (Fig. 3). Second, the northeast trade winds had mostly a terrestrial origin, and would have broadened the zone with dry conditions.

The northward migration of the climate zones from the Paleocene to the Oligocene, including the dry belt, appears to be consistent with the Paleogene changes of the global boundary conditions as reflected by marine $\delta^{18} \mathrm{O}$ records ( $\mathrm{Za}-$ chos et al., 2001) (Fig. 5a). The Paleocene Earth is commonly considered ice-free. Glaciations may have started on Antarctica at $\sim 43 \mathrm{Ma}$ ago and then expanded in the early Oligocene at $~ 34 \mathrm{Ma}$ (Miller et al., 1987; Zachos et al.,
2001). Ice-volume on Antarctica during the early Oligocene glaciation may have reached $\sim 70 \%$ of the present-day volume (Zachos et al., 1992). Although recent evidence of ice-rafting (Moran et al., 2006) revealed nearly synchronous bipolar cooling events during the Cenozoic, impermanent ice, probably mainly mountain and piedmont glaciers in the Northern Hemisphere, only appeared since the late Miocene, 10-6 Ma (Lear et al., 2000).

These global scenarios in the Paleogene, characterized by great ice-sheets in Antarctica and ice-free or sporadic ice in Arctic, imply a much greater asymmetry of ice-conditions between the two hemispheres. Under the present-day global boundary conditions, the northern front of the southern hemispheric trade winds, i.e. the ITCZ, penetrates northwards to $\sim 22-24^{\circ} \mathrm{N}$ in summer and to $\sim 4^{\circ} \mathrm{N}$ in winter (Lezine et al., 2007) due to hemispheric asymmetry. The development of the Antarctic ice in the Eocene and early Oligocene (Zachos et al., 2001) would have forced global climate zones to migrate northwards, providing a likely explanation for the northward migration of the dry belt in Asia from the Paleocene to the Oligocene (Fig. 3).

Although these interpretations remain hypothetical and need to be tested by climate models, a meridional shift of the atmospheric circulation induced by greater extents of sea ice over the Southern Atlantic and Southern Ocean has been demonstrated by the late Quaternary geological records (Iriono, 2000; Markgraf et al., 2000; Stuut and Lamy, 2004; Gersonde et al., 2005; Lambert et al., 2008). A climate model (Cox et al., 2008) shows that reduced aerosol pollution in the Northern Hemisphere also favors a northwards shift of the atmospheric circulation. The much weaker dust intensity during the Paleogene, as evidenced by the lack of loess deposits in China and the low dust accumulation rates in the North Pacific (Rea et al., 1985; Rea, 1994), may also account for the northwards shift of the climate zones.

This explanation is also supported by the increased humidification in the southern part of China from the Eocene to Oligocene (Fig. 3), suggesting the existence of a circulation that brought moisture to the region. It might correspond to the so-called tropical monsoon (Chase et al., 2003) resulted from the penetration of Southern Hemisphere trade winds into the Northern Hemisphere, primarily driven by the seasonal oscillations of planetary circulations (Chase et al., 2003).

In summary, the climate in Asia in the Paleogene was dominated by a zonal pattern attributable to the planetary circulation system. Despite a possible monsoon regime in the tropical regions, its intensity was not strong enough to dominate the climate of the Asian continent.

\subsection{Neogene climate pattern}

The Miocene climate patterns (Fig. 4) are entirely different from those in the Paleogene (Fig. 3). Indicators of arid conditions are mainly distributed in northwest China. 

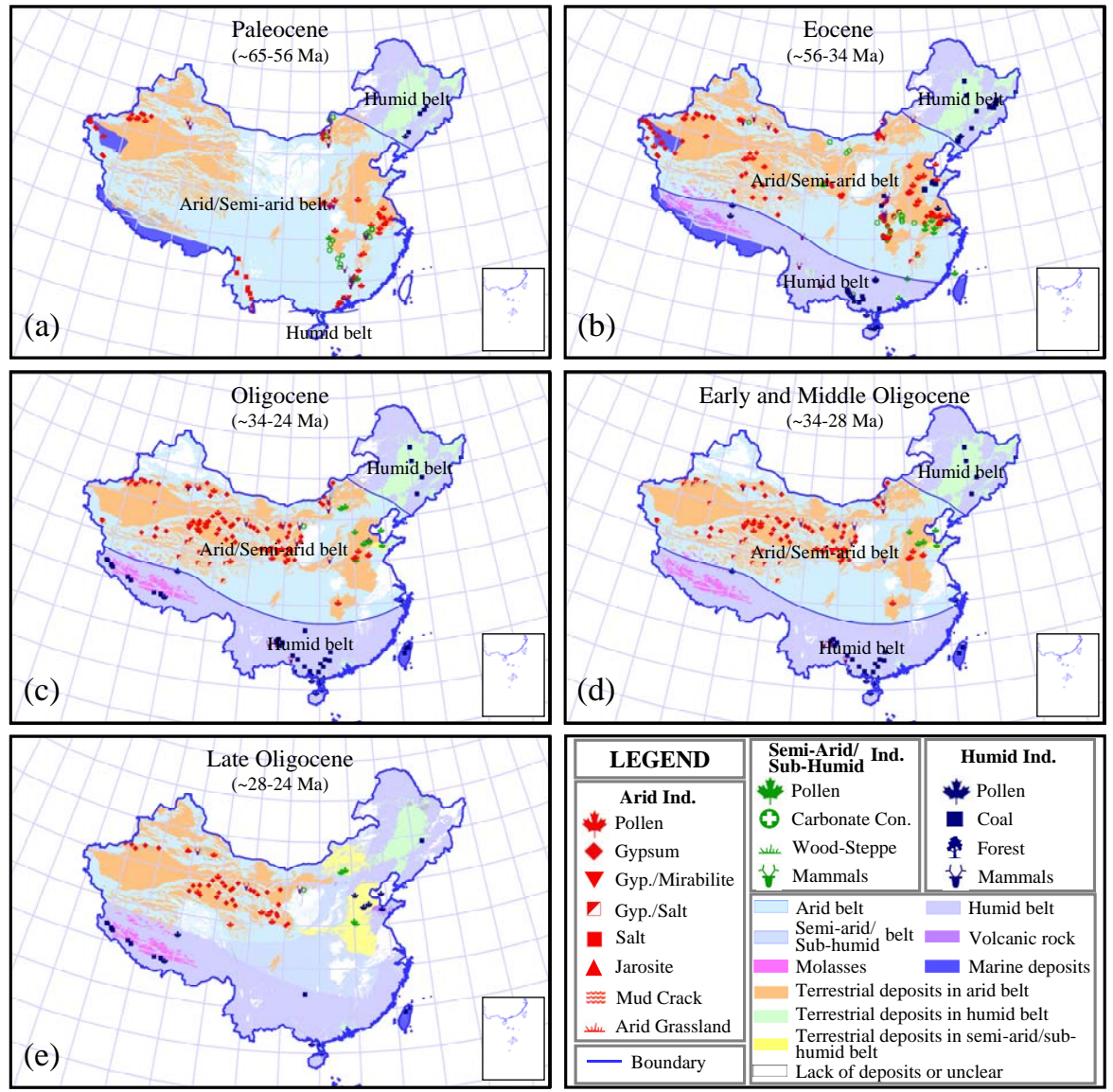

Fig. 3. Paleogene environmental patterns in China. (a) Paleocene; (b) Eocene; (c) Oligocene; (d) Early and middle Oligocene; (e) Late Oligocene. The data sources are given in Supplementary Material http://www.clim-past.net/4/153/2008/cp-4-153-2008-supplement.pdf. A geographical information system was used to illustrate the distribution of environmental indicators. The base map is from China Geological Survey (2001). Data on the distribution of the Cenozoic terrestrial deposits are from Chinese Stratum Thesaurus Editorial Board (1999).

The middle reaches of the Yellow River were dominated by semi-arid conditions. In contrast, indicators of humid conditions spread widely across the southwestern and southeastern parts. This spatial pattern is highly similar to the present-day climate pattern in China (Fig. 1a).

Earlier studies inferred two important Miocene boundaries of climate changes in Asia, one in the early Miocene (Shi et al., 1999; Guo et al., 2002) and the other in the late Miocene (Quade et al., 1989; Kroon et al., 1991; An et al., 2001). To more accurately examine this problem, the Miocene data are separated into the early, middle and late Miocene parts (Fig. 4b-d). Data for each interval are abundant enough to define the climate patterns clearly. They show the existence of a pattern similar to the modern one since the early Miocene (Zhang and Guo, 2005). The Pliocene pattern (Fig. 4e) is also similar to the Miocene one, except that the far northeastern part is marked by semi-arid conditions, representing a slight humidification compared to the late Miocene.
The humidification in the southeast and southwest of China since the early Miocene firmly indicates the strong influence of the southeast and southwest summer monsoons. It also supports a notion of synchronous onsets/strengthenings of the two summer monsoons rather than largely diachronous developments. The Neogene location of drylands at much higher latitudes indicates that the aridity was not caused by the subtropical high-pressure zone. Instead, the similar location to the present-day drylands indicates typical inland-type deserts.

In summary, the spatial distributions of the geological indicators clearly reveal that (1) the zonal climate pattern linked to the planetary circulation system was transformed to a monsoon-dominated pattern similar to the present-day one; (2) the low-latitude drylands related to the subtropical high-pressure zone disappeared while inland-type deserts at higher latitudes formed; and (3) both the humidification in southwest and southeast China and the appearance of the northwest drylands were closely coupled, suggesting a joint change of circulation and aridity, and hence, dynamic links 

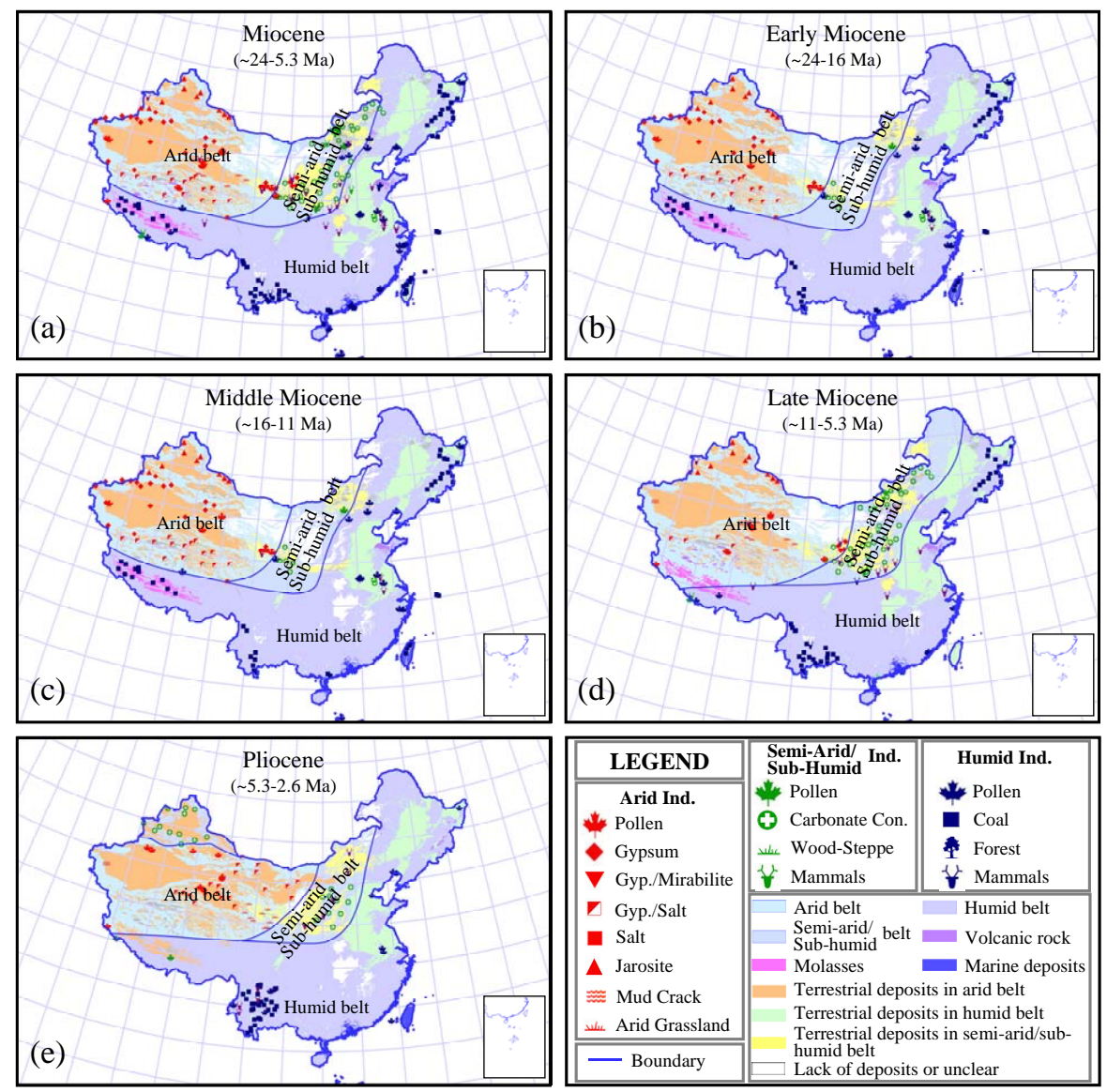

Fig. 4. Neogene environmental patterns in China. (a) Miocene; (b) Early Miocene; (c) Middle Miocene; (d) Late Miocene; (e) Pliocene. Data sources are the same as noted in the caption of Fig. 3.

between them; and (4) these changes had occurred at least by the early Miocene. The climate effects of the subtropical high-pressure zone, which would generate dry conditions at low-latitudes (Houghton, 1984), were largely weakened during the Neogene due to the strong influence of the summer monsoons.

\section{Miocene loess-soil sequences as indications of mon- soon regime and inland-deserts}

Eolian dust deposits spread widely across the middle reaches of the Yellow River in the Loess Plateau (Liu, 1985). The region is delimited by the Liupan Mountains into the eastern and western parts, with the Asian inland deserts to the north and northwest, and the Himalayan-Tibetan Plateau to the southwest (Figs. 1a and 2). Modern observations indicate that eolian dust is mainly derived from inland deserts and transported by the Asian winter monsoon (Liu, 1985) while rainfall in the region is mainly brought by the southeast summer monsoon (An et al., 1990; Liu and Ding, 1998) and to a lesser extent, by the southwest summer monsoon (Chen et al., 1991).

To date, three main eolian formations have been identified in the Loess Plateau. These include the well-known loesssoil sequences of the last 2.6 Ma (Liu, 1985; Kukla et al., 1990; Ding et al., 1994; An et al., 2001), the Hipparion RedEarth of eolian origin, also referred to as Red-Clay (2.6$8.0 \mathrm{Ma}$ ) and only found in the eastern Loess Plateau (Sun et al., 1997; Ding et al., 1998; An et al., 2001; Guo et al., 2004), and the Miocene and Pliocene loess-soil sequences recently found in the western Loess Plateau with a combined time coverage from 22 to $3.5 \mathrm{Ma}$ (Guo et al., 2002; Hao and Guo, 2004, 2007; Liu et al., 2005). These eolian formations provide a near continuous terrestrial record of paleoclimate for the past $22 \mathrm{Ma}$.

3.1 Onset of loess deposition roughly coupled with the changes of climate pattern

Miocene loess deposits were firstly found in the western Loess Plateau (Guo et al., 2002) near Qin' an (QA-I and QAII sections), Gansu Province (Fig. 2). Their eolian origin 


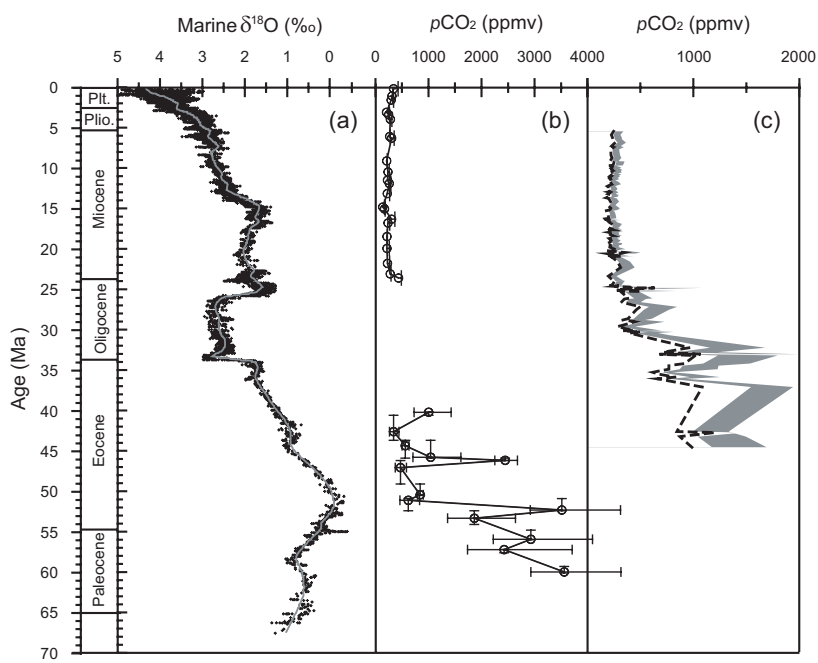

Fig. 5. Variations of global temperature/ice volume and proxy estimates of the Cenozoic atmospheric concentration of $\mathrm{CO}_{2}$. (a) Marine $\delta^{18} \mathrm{O}$ records of benthic foraminifera as an indication of global temperature and ice volumes (Zachos, et al., 2001); (b) Boron isotope-based estimates of atmospheric $\mathrm{CO}_{2}$ levels for the past $60 \mathrm{Ma}$ (Pearson and Palmer, 2000); (c) Carbon isotope based estimates of Cenozoic atmospheric $\mathrm{CO}_{2}$ levels (Pagani et al., 2005). The shadowed band indicates the maximum and intermediate estimates and dashed line indicates the minimum estimates.

is attested by (1) the presence of several hundred paleosols and interbedded loess layers that were significantly affected by pedogenesis, indicative of subaerial environments (Guo et al., 2002); (2) the fine silty texture throughout the $\sim 16-\mathrm{Ma}$ sequence with maximum grain-size mostly $<120 \mu \mathrm{m}$ (Guo et al., 2002; Qiao et al., 2006); (3) the angular morphology of quartz grains typical of eolian dust deposits (Guo et al., 2002; Liu et al., 2006); (4) the similar geochemical properties to the Quaternary loess and to the average composition of the upper continental crust (Liang et al., 2006), a basic feature of loess deposits (Jahn et al., 2001); (5) the well-preserved, abundant and randomly distributed land snail fossils in both soil and loess layers, along with the lack of aquatic and amphibian species throughout the sequences ( $\mathrm{Li}$ et al., 2006a, 2006b); and (6) rock magnetic properties typical of eolian deposits (Hao et al., 2008). Spatial investigations showed that the Miocene eolian deposits mantle the highlands across a broad region of the western Loess Plateau (Yuan et al., 2007).

We have dated five Miocene loess-soil sections (Fig. 2) using magnetostratigraphy. These include the QA-I (22-6.2 Ma) and QA-II (21.6-7.4 Ma) (Guo et al., 2002), QA-III (21.4-11.4 Ma) (Hao and Guo, 2007), QA-IV (Miziwan site, 18.5-11.6 Ma) (Liu et al., 2005) and ML-V (Gaojiazhuang site) in this study (Fig. 6). The variable basal ages of the sections are related to their different topographic locations. A loess section near Xining containing a Miocene portion younger than $14 \mathrm{Ma}$ was also reported ( $\mathrm{Lu}$ et al., 2004).
These results provide several lines of new information about this unique terrestrial record.

1. These sections have stratigraphies and magnetic susceptibility time series that are spatially correlative (Guo et al., 2002; Liu et al., 2005; Hao and Guo, 2007). This is clear in the correlations between ML-V and QA-I (Figs. 6 and 8), separated by $\sim 75 \mathrm{~km}$. Such high spatial correlativity is characteristic of eolian deposits and also attests to the relative continuity of the sequences.

2. The spatial coverage of these sites, as well as our geomorphic investigations (Yuan et al., 2007), reveals widespread Miocene eolian deposition in northern China, and their significance for paleoclimate at larger regional scales. Miocene eolian dust input has also been identified as the main source of fine-grained sediments in some fluvial-lacustrine basins in the region (Garzione et al., 2005). Recently, a set of fine-grained sediments beneath a 15-Ma basalt sheet near Nanjing has been identified as eolian deposits (Zhang et al., 2007) suggesting that the southern boundary of the Miocene eolian deposition might have reached as far south as the Yangtze River.

3. The lower boundaries of these sections indicate that loess deposition in northern China started at least in the early Miocene. The basal age of the QA-I section, $\sim 22 \mathrm{Ma}$ (Guo et al., 2002), still represents the oldest up to date. This is approximately consistent with the major change of climate patterns in Asia discussed above, confirming a major reorganization of climate regime.

3.2 Miocene loess as direct evidence of inland deserts in Asia

Loess deposits cover $\sim 10 \%$ of the land surface and are found in variable environments (Liu, 1985; Tsoar and Pye, 1987; Pye, 1995). Drylands are the most important dust sources and the resulted loess deposits are known as hot loess (Obruchev, 1933, but see Liu, 1985). In contrast, loess deposits around glacial areas are referred to as cold loess, with distributions spatially restricted to periglacial environments (Liu, 1985). Loess deposits usually cover terraces of large rivers, mostly due to dust deflation from fine-grained fluvial materials during glacial periods (Qiao et al., 2003; Zoller et al., 2004; Johnson et al., 2007). Their distribution is clearly linked to river valleys. Loess deposits are also frequently found in coastal regions where dust was mostly derived from continental shelves exposed to wind erosion during the times of low sea level (Zhao, 1996). Some loess deposits may result from a mixture of sources, such as the unusually thick loess deposits on some river terraces in northern China (Jiang et al., 2004) where local fluvial sources and remoter desert sources would have co-contributed.

Whatever the main sources of eolian dust, the formation of loess fundamentally requires (1) a sustained source of dust, 


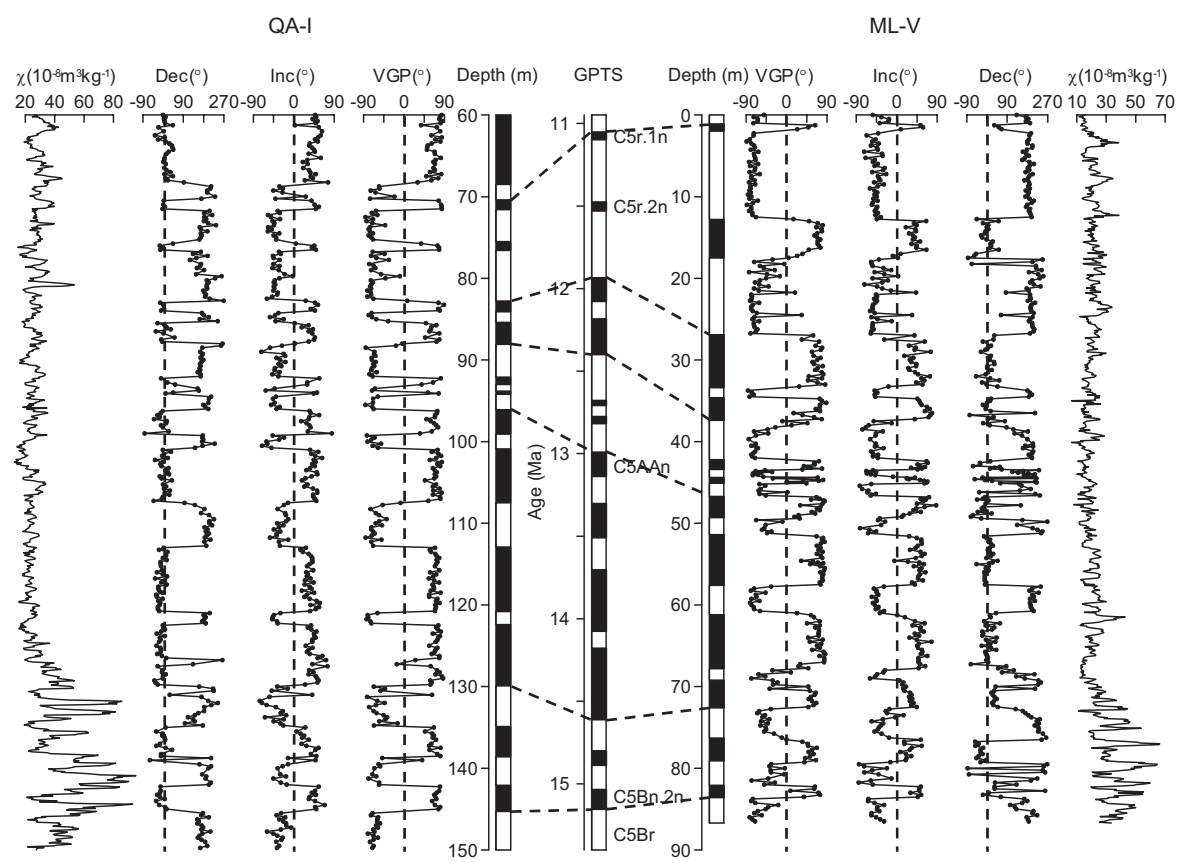

Fig. 6. Magnetostratigraphy and magnetic susceptibility $(x)$ of ML-V (Gaojiazhuang site $\sim 75 \mathrm{~km}$ south to $\mathrm{QA}-\mathrm{I}, 105^{\circ} 43 / \mathrm{E}, 34^{\circ} 24 / \mathrm{N}$ ) Miocene loess-soil sequence and correlation with QA-I. Declination (Dec), inclination (Inc) and virtual geomagnetic pole (VGP) latitudes are shown. Correlation of the ML-V geomagnetic polarity with the standard geomagnetic polarity timescale (GTPS, Cande and Kent, 1995) dates the section from 15.41 Ma to 11.01 Ma. Data of QA-I are from Guo et al. (2002). The ML-V section rests on Devonian phyllite and is overlain by thick colluvia mostly derived from loess materials. Paleomagnetic measurements were made on 376 samples at 20 $25 \mathrm{~cm}$ intervals in the Paleomagnetism Laboratory of Institute of Geology and Geophysics, Chinese Academy of Sciences using stepwise thermal demagnetization as described in Guo et al. (2002). 94\% of the samples gave reliable characteristic remanence directions. Magnetic susceptibility was measured on air-dried samples at $10 \mathrm{~cm}$ intervals using a Bartington susceptibility meter.

(2) adequate wind energy to transport the dust, and (3) a suitable accumulation site (Pye, 1995). Dust deflation only occurs in areas with poor vegetation cover (Tsoar and Pye, 1987; Pye, 1995). Although fine-grained material is commonly available in tectonically active regions, dense vegetation cover often prevents the fine materials from being deflated. An example is the humid Yunnan region in southwest China where tectonics and erosions are intense but loess deposition only occurred along river valleys at small scales. The remarkably thick and widespread loess of China and Central Asia results from the long-term persistence of extensive dryland dust sources (Pye, 1995).

The Miocene eolian deposits in northern China are undoubtedly hot loess because of their wide distribution and nearly continuous temporal coverage. Their desert origin is also supported by the angular morphology of the quartz fraction extracted from these loess samples (Fig. 7a and b). Scanning electronic microscope (SEM) observations show that a majority of quartz grains are finer than $100 \mu \mathrm{m}$ in diameter, mostly ranging from 10 to $30 \mu \mathrm{m}$. Most grains have irregular and angular shapes and many are characterized by sharp edges and conchiform fractures. The angular grains resulted from mechanical collisions of eolian sandy grains, salt dis- integration and freeze-thaw weathering in the desert regions (Liu, 1985; Tsoar and Pye, 1987; Pye, 1995). Because dust was transported by wind in suspension, their angular shapes were not abraded.

The elemental geochemistry signatures of the Miocene loess (Liang et al., 2006) are also very similar to the average composition of the upper continental crust, indicating that the dust materials were all derived from well-mixed sedimentary protoliths which underwent numerous upper-crustal recycling processes (Taylor et al., 1983). These compositions suggest that the materials were derived from wide areas, such as desert lands. Local sources of small scale would tend to have more specific geochemical signatures.

Thus, the Miocene loess deposits in northern China provide pertinent evidence on the following crucial features relative to the Cenozoic history of Asian drying.

1. They indicate the existence of sizeable deserts in the Asian inlands by $22 \mathrm{Ma}$ ago as dust sources (Guo et al., 2002). Because the onset of loess deposition matches the reorganization of climate patterns, these deserts must be inland-type rather than planetary-type. These also indicate a joint change in inland aridity and the atmospheric circulation. 

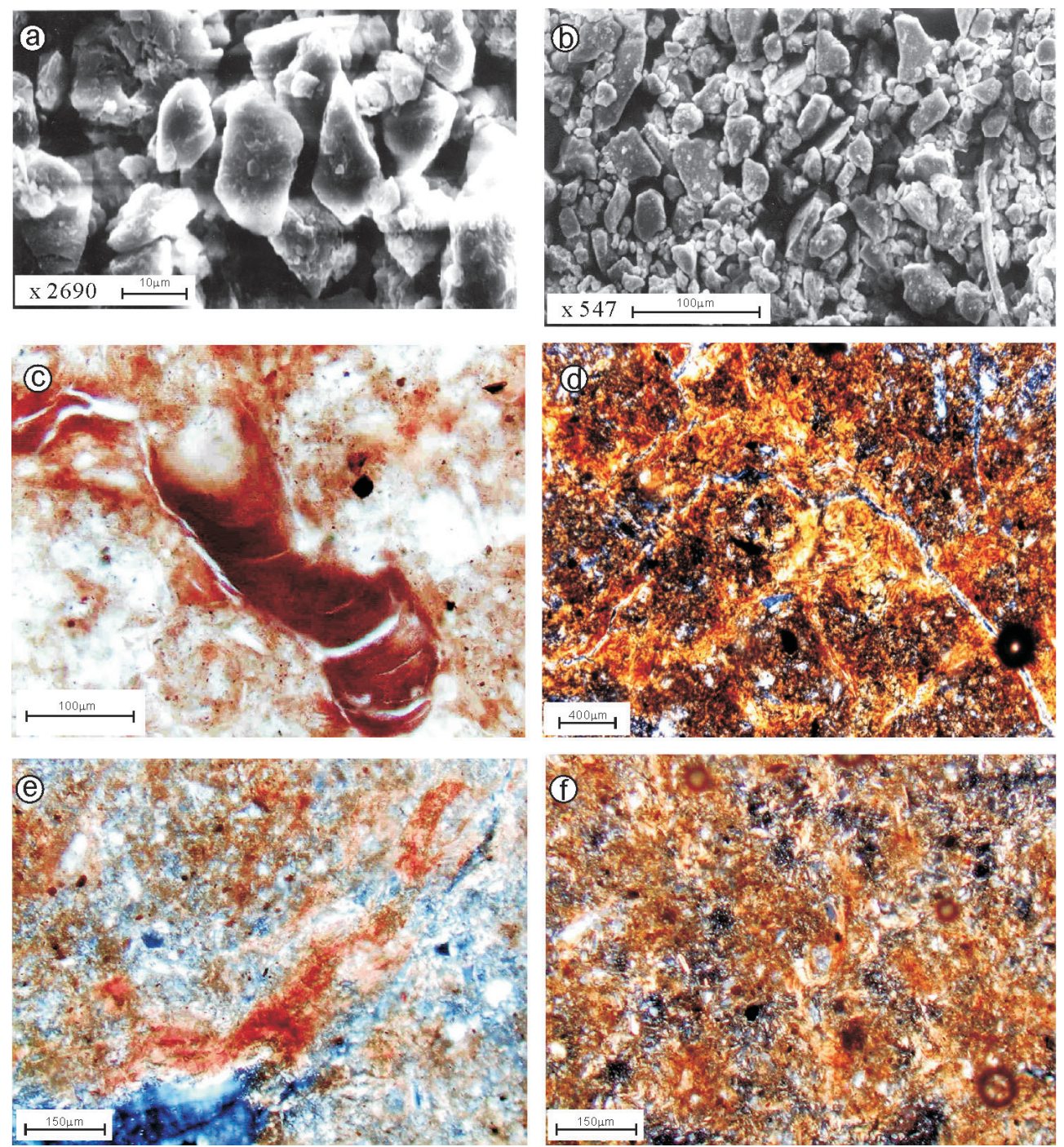

Fig. 7. Quartz grain morphology of early Miocene loess samples and micromorphology of the early Miocene paleosols from QA-I. (a) Scanning electronic microscopic (SEM) picture of quartz grains in Miocene loess samples (QA-I, $250 \mathrm{~m}$ ); (b) SEM picture of quartz grains in Miocene loess samples (QA-I, 252.6 m); (c) Clay coatings in an early Miocene soil (QA-I, $253.1 \mathrm{~m}$, plain-polarized light); (d) Clay coatings and intercalations with high birefringence (QA-I, $253.1 \mathrm{~m}$, cross-polarized light); (e) Clay illuvial features in the forms of intercalations within the groundmass (QA-I, $214.8 \mathrm{~m}$, cross-polarized light); (f) Groundmass of an early Miocene soil showing the strong argilization (QA-I, $211.8 \mathrm{~m}$, cross-polarized light).

2. The near-continuous development of eolian sequences in northern China, from the early Miocene to the Holocene, implies that inland deserts have been constantly maintained over the past $22 \mathrm{Ma}$ despite drastic changes in global climates during the Neogene and Quaternary (Miller et al., 1998; Zachos et al., 2001).

\subsection{Miocene dust transport and Asian winter monsoon}

A large collection of observational evidence indicates that the Quaternary loess deposits in northern China were mainly transported by the northwest winds in the Asian winter monsoon (Liu, 1985; An et al., 1990; Ding et al., 1995; Liu and
Ding, 1998). This inference has been confirmed by the spatial variations of eolian grain-size in the Loess Plateau region, ranging from coarser in the northwestern part to finer in the southeastern part (Liu, 1985; Ding et al., 1995). Recent examination on the late Miocene-Pliocene Red-Earth (Miao et al., 2004) revealed a similar pattern of eolian grain-size, indicating a dominant role for the winter monsoon in dust transport since $\sim 8 \mathrm{Ma}$ ago.

The onset of eolian dust deposition by $22 \mathrm{Ma}$ ago attests to the presence of a circulation sufficiently energetic to carry eolian dust from the deserts to the Loess Plateau region (Guo et al., 2002). Several lines of evidence suggest that this 
circulation was also the winter monsoon.

1. Loess has been continuously deposited in the middle reaches of the Yellow River since at least $22 \mathrm{Ma}$ ago and the location of drylands in Asia (Fig. 4) has been similar to the present-day (Fig. 1). This evidence implies that the dust-carrying winds must have had a northern origin from the available dust sources, consistent with the modern trajectory of the Asian winter monsoon.

2. Although more sophisticated geochemical approaches may discriminate among the relative contributions of different deserts to loess deposits (Chen et al., 2001; Sun, 2002), the similarity in the elemental geochemistry between the Miocene loess and those of the last $8 \mathrm{Ma}$ (Guo et al., 2002; Liang et al., 2006) supports broadly comparable source areas and dust transporting trajectories over the past $22 \mathrm{Ma}$, and hence the presence of the winter monsoon circulation.

To further address this issue, grain-size analyses were conducted on samples dating from 15.4 to $11.1 \mathrm{Ma}$ at QA-I and ML-V (Gaojiazhang site), 75 km south to QA-I (Fig. 2). The analyses reveal similar trends of grain-size variations along the two sections, but significantly finer textures at the southern ML-V site (Fig. 8). The average median grain-size at ML-V is $\sim 1 \mu \mathrm{m}$ finer than for QA-I. These new data have three implications.

1. Similar to the magnetic susceptibility time series (Liu et al., 2005; Hao and Guo, 2007), grain-size variations in the Miocene loess-soil sequences are also spatially correlative, again characteristic of eolian deposits.

2. The grain-size gradients indicate that the source areas lie to the north of the Loess Plateau, and thus in the inland deserts.

3. The patterns require north-to-south circulation (the Asian winter monsoon). The establishment of northerly winds is regarded as the main criteria of the Asian monsoon system (Liu and Yin, 2002). Because of the close relationship of the winter monsoon with the Siberian high-pressure center, we believe that the Siberian High would have also formed or greatly intensified by $22 \mathrm{Ma}$ ago.

Unfortunately, available early Miocene sections are not ideally located for examining grain-size gradients prior to $15 \mathrm{Ma}$.

3.4 Early Miocene soils in loess as evidence of a monsoon climate regime

Loess layers are deposited during relatively dry-cold periods while soils developed during more humid-warm intervals. Because soil formation requires a substantial amount of rainfall, the numerous paleosols in the Miocene eolian sequences also imply the existence of other circulation branches able to bring moisture from the ocean to the south. Consequently, the alternations between loess and soil layers indicate cyclical orbital-scale occurrences of dry and humid conditions in northern China (Guo et al., 2002).

To further characterize the circulation characteristics, we examined properties of the early Miocene paleosols. Micromorphology examination reveals abundant clay illuvial features (Fig. 7) that are typical of Luvisols (FAO-Unesco, 1974) formed under humid forest environments (Fedoroff and Goldberg, 1982). Their proportions of up to $\sim 30 \%$ are approximately comparable to those of the modern Luvisols in the south of the Yangtze River where annual rainfall is more than $1000 \mathrm{~mm}$ (Zhang et al., 1999). Moreover, a large fraction of the clay illuvial features are in the form of intercalations within the groundmass (Fig. 7d-e). Such illuvial features, commonly described as vertic due to alternative humidification and shrinkage of soil profiles (Hussein and Adey, 1998; Cao and He, 1999), are typical of soils formed under climates with contrasting seasons (Cao and He, 1999). They suggest a strong seasonality in northern China since the early Miocene.

The intensity of clay illuviation of these early Miocene soils was much stronger compared to the most developed soil Quaternary S5-1 soil ( $\sim 0.5 \mathrm{Ma}$ in age) in the relatively humid southernmost Loess Plateau, for which clay illuvial features amount to $\sim 10 \%$ (Guo et al., 1998). Although the relative duration of the seasons may affect pedogenesis, the substantially increased amount of illuvial features in the Miocene soils indicates much more abundant rainfall in northern China during the early Miocene than for the Quaternary. According to the climate patterns since the early Miocene (Fig. 4), most of the moisture must have had a lowlatitude origin in the summer monsoons. In view of the rather dry conditions in northwest China (Fig. 4), the westerlies were unlikely to have provided a significant moisture contribution, because of the extremely long continental trajectory from moisture sources.

Under a climate regime without seasonally alternating circulations, a soil largely represents a sedimentary hiatus (Fedoroff and Goldberg, 1982; Cremaschi et al., 1990), as is the case for most loess-soil sequences in non-monsoon regions. In these regions, soil develops on the parent loess deposited during a dry-cold period, such as late-glacial intervals just prior to the soil-forming interglacial period when dust deposition was negligible (Fedoroff and Goldberg, 1982; Cremaschi et al., 1990). In contrast, paleosols in the loesssoil sequences under a monsoonal climate regime have completely different features resulting from interactions between summer and winter monsoons. In summer, the monsoonal rainfall associated with the high temperature favors pedogenesis, but eolian dust continues to be added to the soil surface in winter and early spring, although at lower intensities than during typical loess deposition periods (Guo et al., 1991, 1993). Thus, dust deposition and soil-formation under 


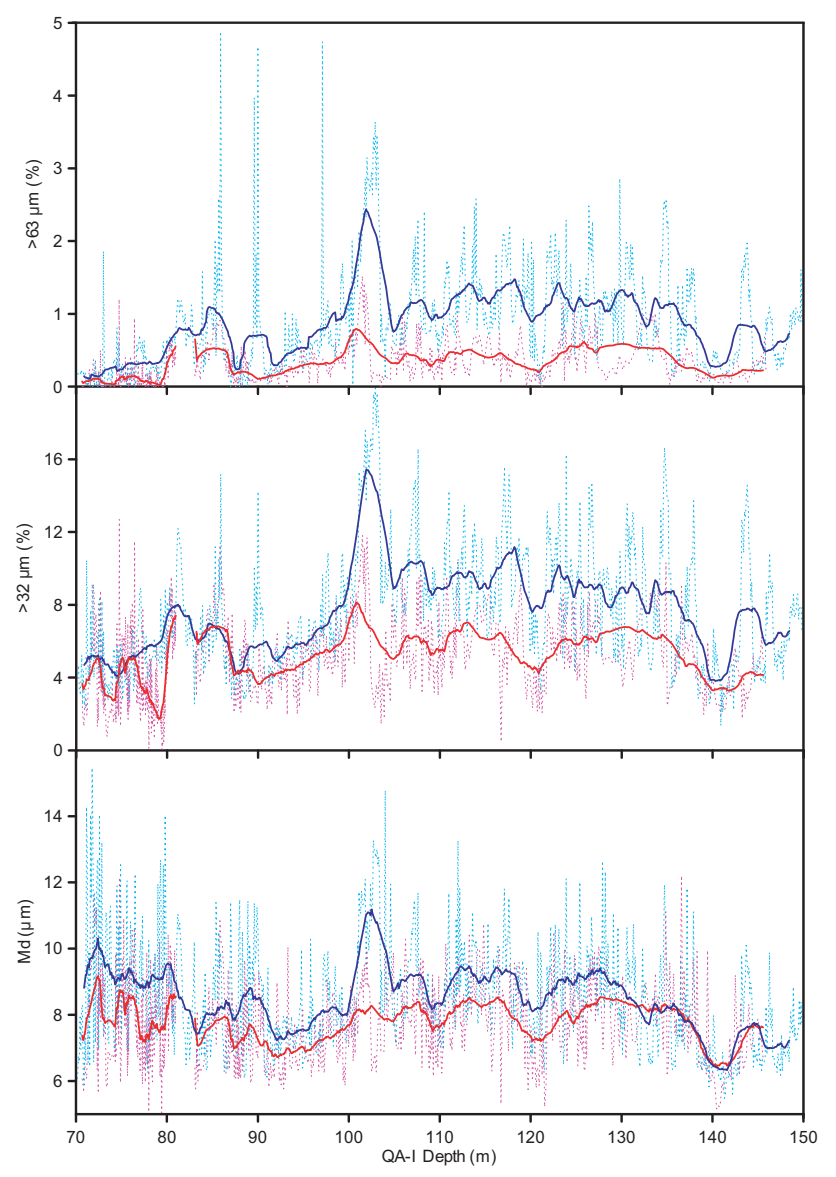

Fig. 8. Comparison of grain-size changes between QA-I (blue lines) and ML-V (red lines). The fine dotted lines represent the data at $10 \mathrm{~cm}$ intervals and the thick lines are 30-point moving averages. ML-V is adjusted to the QA-I depth using magnetic reversals as control points. The grain-size changes shown here correspond to the interval from 15.41 to $11.12 \mathrm{Ma}$. The intervals within ML-V without data correspond to two layers of water-reworked loess with some coarse sands derived from the upper slopes, for which samples were not analyzed. The finer grain-size at the ML-V site indicates northern source locations and northerly dust-carrying winds during the Miocene. Grain-size of 787 samples from QA-I and 868 from ML-V were analyzed using a Malvern Mastersizer-2000 laser particle analyzer with an analytical precision $<1 \%$. They were pretreated with hydrogen peroxide to remove the organic matter, then with hydrochloric acid to remove the carbonates, and with sodium hexametaphosphate for dispersion.

a monsoonal climate regime are competing processes, and the presence of a soil implies that the latter process was predominant (Porter, 2001). These interactive processes lead to the formation of the so-called accretionary soils (Hovan and Rea, 1991; Kemp, 2001) that can be regarded as a strong evidence of a monsoonal climate regime.
Accretionary soils are characterized by specific features (Guo et al., 1991, 1993), three of which allow quick discrimination from non-accretionary soils. First, eolian dust during the soil-forming intervals is usually significantly finer due to the weakened winter monsoon and relatively smaller/remoter sources. This can be detected by examining the grain-size of the quartz fraction, which is highly resistant to weathering and hence independent of the effects of pedogenesis. The quartz fraction of an accretionary soil has finer grainsize than that of the underlying loess, while that of a nonaccretionary soil has similar quartz grain-size to its parent loess. Second, because of the differences in dust grain-size between soil forming and loess deposition periods, the dust composition may also be different, as can be determined using stable elements resistant to post-depositional pedogenesis. Third, accretionary soils usually have highest chemical weathering intensity in the middle of their profiles because of the intensified dust deposition during the late stage of soil development, while non accretionary soils have strongest weathering at the top horizon (Duchaufour, 1983).

To check if the soils in the Miocene loess sequences are accretionary soils, four kinds of analyses were conducted. First, microscopic observations show that the quartz fraction in soils are significantly finer than in the underlying loess layers indicating that the soils were not totally developed from the underlying loess. This conclusion is also confirmed by grain-size analyses on the quartz fraction (Fig. 9a). Second, chemical analyses show an unambiguous difference of chemical composition of the stable elements between the loess and soils that are not affected by the soil-forming processes, indicating a composition differences (Fig. 9b). Finally, the chemical weathering profiles of the soils show stronger weathering intensity in the middle of the profiles (Fig. 9c), followed by decreasing intensity to the top. These properties firmly define the accretionary nature of the paleosols in the Miocene loess deposits, indicating a monsoon climate regime.

In summary, the properties of the Miocene loess-soil sequences require the existence of a typical monsoonal climate in northern China. Still an open question is the relative contribution of moisture from the southeast and southwest summer monsoons to the formation of the Luvisols in the Loess Plateau. Clarification of this question would require several suitably located Miocene loess-soil sections, but these are not yet available. Measurements on the oxygen isotope composition of pedogenic carbonates would also be helpful. Although modern moisture in the Loess Plateau is mostly related to the East Asian summer monsoon due to the elevated Tibetan Plateau to the southwest, a greater contribution from the southwest summer monsoon would be expected during times when the Himalayas and Tibetan Plateau were not as high as it is today, as might be the case for the early Miocene. The results of numerical experiments (Zhang et al., 2007a, b) appear to be supportive to this possibility. 


\section{Other records of the climate reorganization}

Although the onset of loess deposition is roughly consistent in time with the major reorganization of climate patterns, the precise age of this change remains an open question, because the data used for spatial mapping are of coarse resolution and low chronological accuracy while the basal age of the loess sections may depend in part on the tectonic setting of the substrata (Guo, 2003; Hao and Guo, 2004). Also, whether or not this climatic reorganization represents a sudden change or stepwise changes need to be addressed.

During the past five years, we explored for older loess deposits in the Loess Plateau, but did not find any. However, other kinds of records from surrounding regions may provide some insights to this issue. A pollen record from the nearby Linxia fluvial-lacustrine basin (Fig. 10a) showed a drastic increase in the percentage of tree pollen near $\sim 22 \mathrm{Ma}$ (Shi et al., 1999). Because the site was located within the planetarytype dry belt during the Oligocene (Fig. 3) and is presently within the monsoon zone, this vegetation shift would indicate humidification of the region, and thus an enhanced influence of the summer monsoon. Similar trends were shown by a slight decrease in the content of xerophytes at $\sim 23 \mathrm{Ma}$ (Fig. 10b) in a core from the Qaidam basin (Wang et al., 1999) although the region is currently less influenced by the summer monsoons. In a carbon isotope record of terrestrial black carbon reflective of vegetation changes in South China, the earliest high $\delta^{13} \mathrm{C}$ peaks appeared $\sim 20 \mathrm{Ma}$ ago and were interpreted as a support of early monsoon initiation (Jia et al., 2003). A prominent change in the mammalian and floristic regions in China appears to have also occurred in the early Miocene (Song et al., 1983; Qiu and Li, 2005).

A marine eolian record at the LL44-GPC3 site from the North Pacific (Rea et al., 1985; Rea, 1994) shows lower rates of dust accumulation in the Paleogene and roughly doubled rates since $\sim 25 \mathrm{Ma}$ (Fig. 10c). This transition, associated with mineralogy and chemistry changes, was interpreted as representing the time when the core site migrated north from the regime of trade winds to that dominated by eolian transport in the westerlies and the influence of Asian dust sources (Rea, 1994). Recently, a comprehensive geochemical analysis shows a major increase in the delivery of Asian dust material since $\sim 20 \mathrm{Ma}$ (Fig. 10d) at ODP site 1215 from the central Pacific (Ziegler et al., 2007), which was interpreted as recording the development of East Asian monsoon and formation of Asian loess.

These lines of evidence, associated with the Miocene loess records (Guo et al., 2002), suggest that the major changes in the Asian climate regime occurred between 25 and $22 \mathrm{Ma}$ ago, and most of them support an age close to $22 \mathrm{Ma}$. From these insights, we speculate that discovery of older loess-soil sections could yet be made in northern China but probably not more than a few million years older.
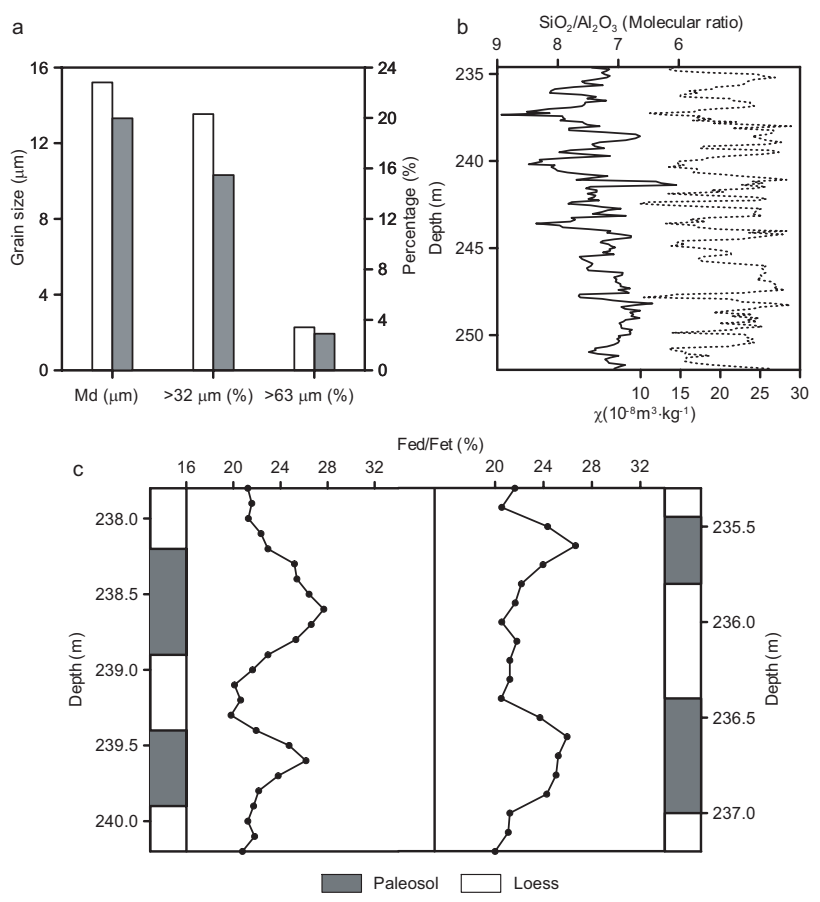

Fig. 9. Accretionary properties of the early Miocene paleosols. (a) Comparison of median grain-size (Md) and the proportions of the $>32 \mu \mathrm{m}$ and $>63 \mu \mathrm{m}$ fractions of quartz particles between soils and loess layers, showing the accretion of finer eolian dust during soilforming periods. 30 soil and 30 loess samples were analyzed along QA-I (totally $253.1 \mathrm{~m}$ in thickness). The quartz fraction was extracted using the sodium pyrosulfate fusion-hydrofluorosilicic acid method (Xiao et al., 1995). X-Ray diffractions of the extracted fraction indicate a quartz purity of more than $95 \%$. Grain-size of the quartz samples was analyzed using a Malvern Mastersizer-2000 laser analyzer. (b) Variations of $\mathrm{SiO}_{2} / \mathrm{Al}_{2} \mathrm{O}_{3}$ molecular ratio along an early Miocene portion of QA-I showing lower values in soils than in loess layers. Because this ratio has been shown to reflect mainly the eolian grain-size prior to pedogenic affection (Peng and Guo, 2001; Guo et al., 2004), its lower values in soils indicate continuous dust deposition during the soil-forming periods, but with finer grain sizes. Alternations between soil and loess layers are illustrated by the fluctuations of magnetic susceptibility, higher in soils and lower in loess. $\mathrm{SiO}_{2}$ and $\mathrm{Al}_{2} \mathrm{O}_{3}$ contents were analyzed by $\mathrm{X}$ Ray fluorescence using a Philips PW-1400 unit with an analytical uncertainty of $2 \%$. (c) Variations of Fed/Fet ratio along two early Miocene portions at QA-I as examples show highest weathering at the middle of the soil profiles. Fed/Fet is a chemical weathering index (Duchaufour, 1983) that measures the proportion of iron oxides and hydroxides liberated by chemical weathering from iron-bearing silicate minerals and has been successfully applied in the Quaternary loess of China (Guo et al., 1996, 2000). 


\section{Causes of climate reorganization}

The new results therefore confirm previous evidence that the climate in Asia experienced a transition from a zonal climate pattern to a monsoon-dominated one near the Oligocene/Miocene boundary, by $22 \mathrm{Ma}$ ago. This reorganization was marked by the joint onsets/strengthenings of the Asian summer and winter monsoon circulations and inlandtype deserts. After this transition, the role of the summer Subtropical High was largely weakened, while that of the winter Siberian High was reinforced. The similarity of climate patterns through the Neogene and Quaternary, and continuous loess deposition over the past $22 \mathrm{Ma}$ indicate that the monsoon-dominated climate and the inland deserts have constantly been maintained since their formation.

The causes of the Asian monsoons and inland desertification have been objectives of numerous studies. Earliest theories emphasized the role of land-sea thermal contrast and its link to monsoon phenomena (Halley, 1986). However, these theories cannot explain the onset of a broad monsoondominated regime by the early Miocene. Normal seasonal oscillations of planetary circulations (Flöhn, 1956) such as the inter-tropical convergence zone (ITCZ) may explain the presence of monsoons in tropical regions, but not the deep penetration of the ITCZ and summer monsoons into eastern Asia since the early Miocene as indicated by the presence of well developed soils.

Although the Cenozoic global cooling trends had significant impacts on the Asian monsoon climate in the past $6 \mathrm{Ma}$ (Ding et al., 1995; Guo et al., 2004), they are unlikely to account for the major reorganization of climate pattern by $22 \mathrm{Ma}$ ago because the most prominent changes in global icevolume and temperature, as documented by the marine $\delta^{18} \mathrm{O}$ records (Miller et al., 1998; Zachos et al., 2001), are not correlative with the major changes in Asia (Fig. 5a). Also, the consistently maintained monsoon-dominated climate pattern and inland deserts in the past $22 \mathrm{Ma}$, as evidenced by nearcontinuous eolian sequences in China and the paleoenvironmental maps (Fig. 4), indicate that ice volume changes had not rearranged the basic climate pattern in Asia.

Other possible factors include the decreasing atmospheric concentration of $\mathrm{CO}_{2}$, which would cause global cooling, and consequently intensify Asian aridity and the winter monsoon. Proxy estimates (Perason and Palmer, 2000; Pagani et al., 2005) suggested large $\mathrm{CO}_{2}$ decreases at $\sim 50 \mathrm{Ma}, 30 \mathrm{Ma}$ and $24 \mathrm{Ma}$ (Fig. $5 \mathrm{~b}$ and c). Although the fall at $\sim 24 \mathrm{Ma}$ is close in time to the Asian climate change, changes in $\mathrm{CO}_{2}$ level are not likely by themselves be the main cause of the climate-pattern rearrangement. Consequently, regional factors must have played a dominant role.

Climate model experiments have focused on two main factors: uplift of the Himalayan-Tibetan complex and retreat of the Paratethys Sea, an epicontinental sea still largely opened during the Paleogene (Dercourt et al., 1993). Uplift could shift the Asian climate from a zonal pattern to a non-zonal one (Manabe and Terpstra, 1974). The growing elevation (Kutzbach et al., 1989; 1993; Ruddiman and Kutzbach, 1989; Ruddiman et al., 1989; Abe et al., 2003) and expansion of Tibetan Plateau along its northern and eastern margin (An et al., 2001) could lead to drying trends in the Asian inlands and enhance both the summer and winter monsoon circulations. The summer monsoon could be triggered when the Tibetan Plateau reached half its present-day elevation (Prell and Kutzbach, 1992). This threshold of halfelevation also seems to apply to the winter monsoon circulation (Liu and Yin, 2002). Continuing uplift and expansion would alter significantly the thermally forced circulation and enhance continental-scale summer and winter monsoons and central Asian aridity (An et al., 2001). In northern China, the formation of the monsoon climate is mainly marked by the establishment of northerly winter winds, and uplift would have had a more significant effect on the winter monsoon than for the summer monsoon (Liu and Yin, 2002).

An alternative view invokes the impact of the Paratethys retreat (Ramstein et al., 1997; Fluteau et al., 1999) in intensifying the South Asian monsoon and shifting the central Asian climate from temperate to continental conditions. Shrinkage of this epicontinental sea could thus have played a major role in large-scale atmospheric changes along with plateau uplift (Fluteau et al., 1999).

Recently, we attempted to discriminate the effects of these two major factors, and to examine the potential roles of other tectonic changes, on the formation of the monsoondominated climate in Asia using a nine-layer AGCM (Zhang et al., 2006, 2007a,b). Sensitivity experiments show that a progressively elevated Tibetan plateau intensifies both the Asian summer and winter monsoons, increases the seasonal contrast of precipitation in the monsoon zone, and enhances aridity in northwestern China (Zhang et al., 2006, 2007a, b). These findings confirm earlier conclusions that uplift plays an important role in the formation and development of the Asian climate (Kutzbach et al., 1989; 1993; Ruddiman and Kutzbach, 1989; Ruddiman et al., 1989; An et al., 2001; Abe et al., 2003), and also explain the constant maintenance of the monsoon-dominated climate and inland deserts in Asia in the past $22 \mathrm{Ma}$.

Our experiments also revealed that a monsoon-dominated climate and inland deserts can be generated by a 3000-m elevated Tibetan Plateau under most of the Paratethys conditions except one in which the Paratethys Sea is connected with the Arctic Ocean (Zhang et al., 2007a, b). These experiments imply that once the Paratethys becomes disconnected from the Arctic Ocean, a sufficiently elevated Tibetan Plateau $(\sim 3000 \mathrm{~m})$ alone is able to cause formation of both a monsoon-dominated climate and inland deserts in Asia, regardless of the size of the Paratethys. The effects of the plateau are, however, largely weakened when the Paratethys is still connected with the Arctic Ocean.

Experiments with the Paratethys Sea also show that withdrawal of this epicontinental sea increases precipitation in 


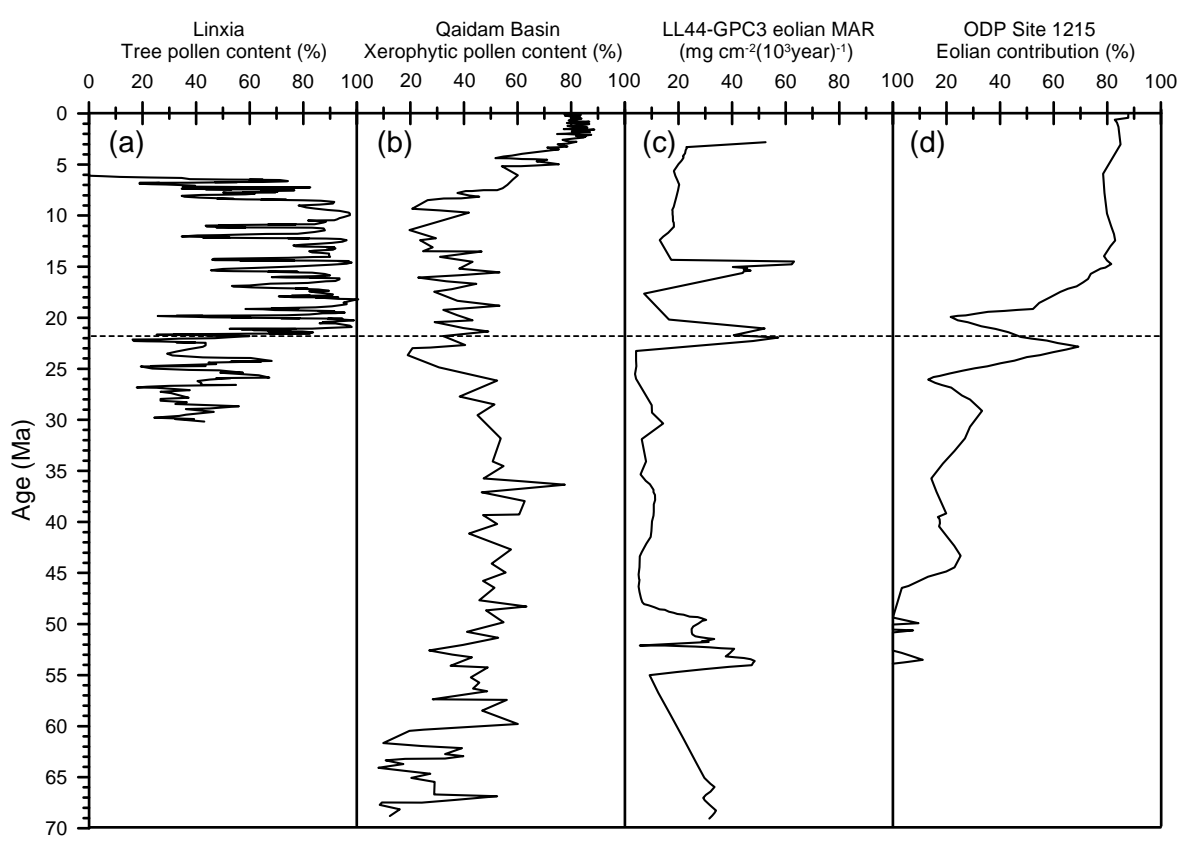

Fig. 10. Relevant geological records of Asian climate changes near the Miocene-Oligocene boundary. (a) Increase in the content of tree pollen $\sim 22$ Ma ago at Linxia (Shi et al., 1999); (b) Decrease in the content of xerophytic pollens in the Qaidan Basin at $\sim 23$ Ma (Wang et al., 1999) ; (c) Cenozoic variations of eolian mass accumulation rate (MAR) at Site LL44-GPC3 from the North Pacific (Rea et al., 1985); (d) Estimated Asian eolian contribution at Site ODP 1215 in the central Pacific showing a large increase at 20 Ma (Ziegler et al., 2007).

the monsoon zone and decreases rainfall in northwest China (Zhang et al., 2007a, b). These results reinforce the earlier conclusion about the role of the Paratethys retreat (Ramstein et al., 1997; Fluteau et al., 1999), and meanwhile show that monsoon climate and inland deserts can be generated when the Paratethys retreats to the Turan Plate whatever the elevation of the Tibetan Plateau (1000-3000 m). The results also suggest that widening of the South China Sea enhances the humidity contrast between southern and northern China (Zhang et al., 2007b).

The effects of Tibetan uplift and Paratethys retreat on the seasonal circulation patterns are somewhat similar for northern China (Fig. 11). In summer, both factors deepen the Asian low pressure and cause south-to-north inflow and bring moisture into China (Fig. 11a and c). In winter, uplift intensifies the Asian high-pressure and lead to northwesterly winds in northern China (Fig. 11b). The Paratethys retreat leads to an anticyclonic anomaly circulation centered over Central Asia and a cyclonic anomaly circulation over Mongolia (Fig. 11d) in winter. The coupled anomalies intensify the northwest winter winds from the inland deserts to the Loess Plateau. Although the anomalies also cause a south-to-north winter flow over eastern China, it would be a moisture-depleted flow because of its terrestrial origin. Our results thus suggest different impacts of Tibetan uplift and Paratethys retreat on the winter circulations, but their common effects are the intensification of the Asian high-pressure and the formation of northwesterly winds in northern China that pick up eolian dust from the inland deserts and transport it to the southeast. These changes are mostly consistent with the seasonal circulation characteristics indicated by the Miocene loess-soil sequences and the Neogene environmental maps (Fig. 4).

As for the geological histories of the three invoked tectonic factors, there is a general consensus about the spreading of South China Sea, which was initiated during the Oligocene and reached a stable spreading state in the early Miocene (Briais et al., 1993; Li et al., 2005, 2006c). This is broadly consistent with the onset of the monsoon-dominated climate. This factor would have enhanced the south-north contrast of humidity (Zhang et al., 2007b). The collision of India and Asia in South Tibet may have begun $\sim 55 \mathrm{Ma}$ or $34 \mathrm{Ma}$ ago (Aitchison et al., 2007) while the subsequent uplift histories of the Tibetan region remain highly controversial. Some views about major uplift focus on several boundaries, including the Eocene and Oligocene at $\sim 45-30$ Ma (Chung et al., 1998; Guo et al., 2006; Rowley and Currie, 2006; Wang et al., 2008), the late Oligocene or early Miocene at 26-18 Ma (Harrison et al., 1992; DeCelles et al., 2007), the mid-Miocene around 14 Ma (Turner et al., 1993; Coleman and Hodges, 1995; Spicer et al., 2003), the late Miocene around $8 \mathrm{Ma}$ (Harrison et al., 1992; Valdiya, 1999; Garzione et al., 2000; Clark et al., 2005; Molnar, 2005) and the PlioPleistocene after 3-4 Ma (Li and Fang, 1999; Zheng et al., 2000). Because the Himalayan-Tibetan Plateau has undoubtedly had a strong effect on moisture transport to the Asian 

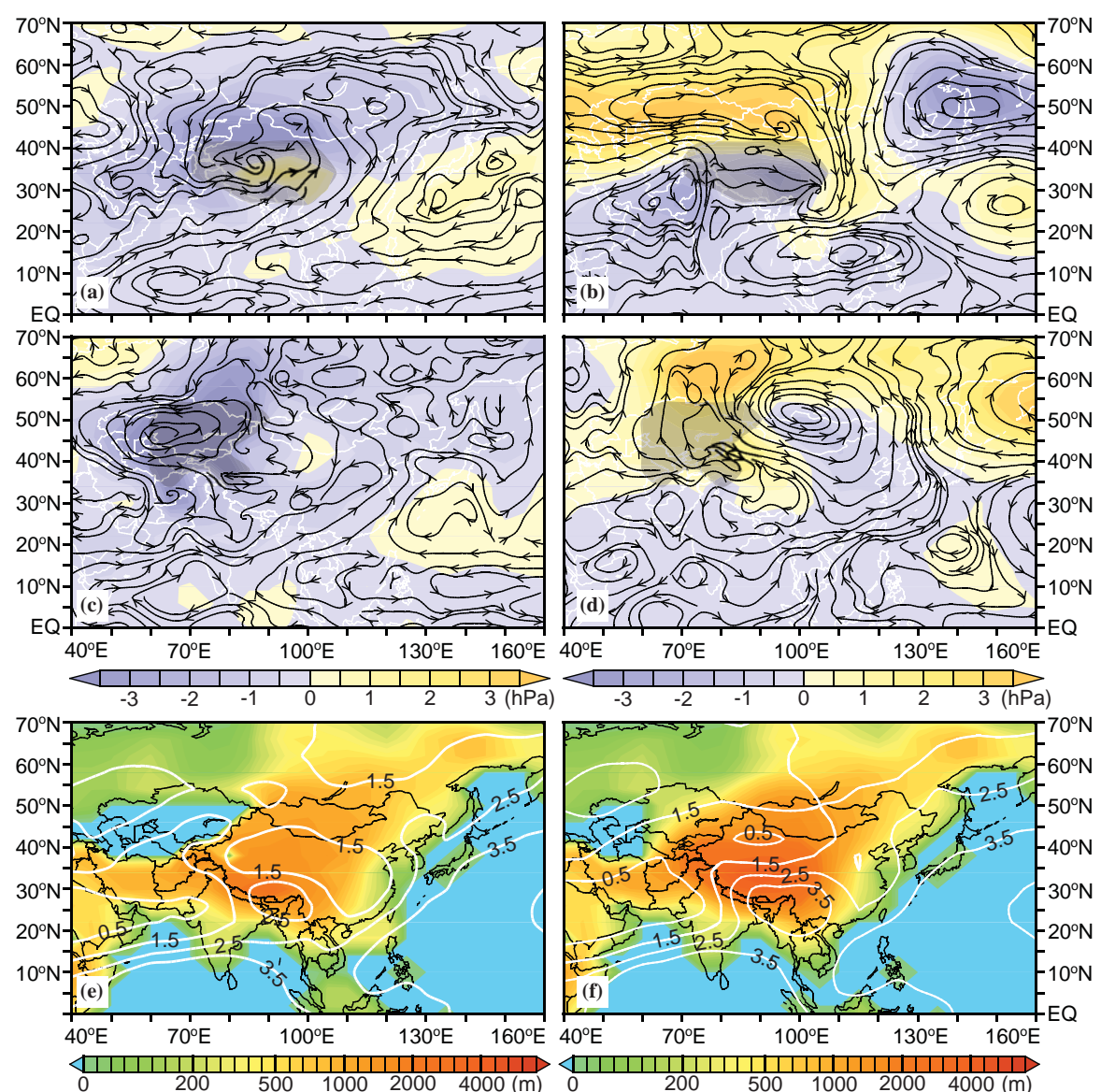

Fig. 11. Effects of Tibetan Plateau uplift and Paratethys retreat on the summer and winter circulation patterns and precipitation fields in Asia (compiled from sensitivity experiments in Zhang et al., 2007b). (a) and (b) show the anomalies of sea-level pressure (color scale, hPa) and $850 \mathrm{hPa}$ wind circulations (stream lines) in summer and winter, respectively, corresponding to uplift of the Tibetan Plateau from half to full elevation. The gray shaded zone indicates the heightened area of the plateau. (c) and (d) show anomalies of sea-level pressure (color scale) and $850 \mathrm{hPa}$ wind circulations (stream lines) in summer and winter, respectively, corresponding to a retreat of the Paratethys Sea from south of Western Siberia to the Turan Plate. The gray shaded zone indicates the sea area that changed into land. (e) and (f) show the comparative precipitation fields under the combined boundary conditions of a low Tibetan Plateau and a large Paratethys Sea, and of a high Tibetan Plateau and a smaller Paratethys Sea, respectively. Color scale shows the elevation of topography with the sea areas in blue. White lines represent isohyets of annual precipitation.

interior, we believe that at least the southern margin of the plateau would have been sufficiently elevated by $22 \mathrm{Ma}$ ago to act as a moisture barrier. This inference is strongly supported by the deposition of debris in submarine fans in the Indian Ocean around this time (Corrigan and Crowley, 1992; Clift, 2006).

During an initial stage of the India and Asia collision, Paratethys would have already separated from the Arctic Ocean (Akhmet'ev et al., 2001; Akhmet'ev and Beniamovski, 2006) while the Tibetan Plateau remained low. Available data suggest shrinkage of this sea from a large extent during the Oligocene and Miocene (Dercourt et al., 1993; Pavelic et al., 2001; Akhmet'ev and Beniamovski, 2006) to a smaller one during the Miocene (Dercourt et al., 1993). This withdrawal is broadly consistent in time with the suggested chronological ranges of Tibetan uplift and the onsets of monsoon dominant climate and inland deserts in Asia.

The fact that a monsoon-dominated climate and inland deserts were already formed by $22 \mathrm{Ma}$ ago provides an environmental clue for a further evaluation. It suggests that the tectonic conditions had evolved to a threshold by $\sim 22 \mathrm{Ma}$ ago sufficient to cause the climate reorganization. Since both Tibetan uplift and Paratethys retreat were linked with plate tectonics in the region, there is a strong possibility that these two factors evolved more or less synchronously. A large collection of data effectively demonstrates a peak range of regional tectonic changes around the early Miocene (Harrison et al., 1993; Hodell and Woodruff, 1994; Ding and Zhong, 1999; Pavelic et al., 2001; Ding et al., 2004; Guo et al., 
2006). Consequently, the combined effect of Tibetan uplift and Paratethys shrinkage probably triggered the major climate reorganization in Asia.

This combined effect is clear in our numerical experiments (Fig. 11e and f). Under the conditions combining a low Tibetan Plateau and a large Paratethys Sea (Fig. 11e), a roughly zonal field of low precipitation occurs at lower latitudes in China, comparable to the zonal dry belt in the Paleogene (Fig. 3). In contrast, the experiment with a high Tibetan Plateau and a smaller Paratethys Sea yield an arid zone at higher latitudes in northwestern China and increased rainfall in southern China (Fig. 11f). These are comparable with the Neogene climate patterns (Fig. 4).

The exact relationship of Asian climate change relative to tectonics remains to be determined because of uncertainties about the timing and extent of Tibetan uplift and Paratethys retreat, and the inability of models to simulate higher-resolution topography. An increasing amount of evidence suggests diachronous uplifts of the plateau (e.g. Chung et al., 1998; Wang et al., 2008) but detailed reconstructions are not yet possible. Models with higher resolution will also be necessary to investigate the effects of regional mountain ranges, such as the Liupan and Qinling Mountains, which were also likely uplifted during the Neogene. In addition, discriminating the effects of tectonics and global climate changes on the Asian paleoclimate remains an important issue.

Recently, paleo-altimeters based on stable-isotopic indices, such as $\delta^{18} \mathrm{O}$ of soil carbonate (DeCelles et al., 2006), ${ }^{13} \mathrm{C}-{ }^{18} \mathrm{O}$ bonds in carbonate minerals (Ghosh et al., 2006), $\delta^{18} \mathrm{O}$ and $\delta^{2} \mathrm{H}$ of authigenic minerals (Rowley and Currie, 2006; Rowley and Garzione, 2007), as well as paleobotanical indicators (Lu et al., 2001; Spicer et al., 2003) have been developed to address the elevation history of mountains. Most of the results tend to suggest the existence of high-elevation parts of the Tibetan Plateau by or in the early Miocene (Spicer et al., 2003; DeCelles et al., 2006; Rowley and Currie, 2006; Rowley and Garzione, 2007). However, an elevation similar to the present-day one during the early Oligocene, as inferred by some studies (Chung et al., 1998; Rowley and Currie, 2006; Rowley and Garzione, 2007; Wang et al., 2008), may only be local in extent, because an extended plateau at this height would produce the monsoondominated climate pattern in Asia according to climate models (Kutzbach et al., 1989; 1993; Ruddiman and Kutzbach, 1989; Ruddiman et al., 1989; Abe et al., 2003; Zhang et al., $2007 \mathrm{a}, \mathrm{b}$ ), yet geological evidence clearly reveals a planetary climatic pattern in Asia during most of the Oligocene (Fig. 3c). These results, associated with the model outputs and geological records, likely support the notion of diachronous uplifts of the plateau.

Chemical weathering of silicate materials is a process that consumes $\mathrm{CO}_{2}$ (Raymo et al., 1988; Raymo and Ruddiman, 1992). Tectonic uplift may have major impacts on atmospheric $\mathrm{CO}_{2}$ levels by accelerating chemical weathering and increasing the burial of organic matter (Raymo et al., 1988; Raymo and Ruddiman, 1992; Derry and France-Lanord, 1996; Ruddiman et al., 1997). Consequently, reconstruction of the Cenozoic atmospheric $\mathrm{CO}_{2}$ levels might be expected to provide helpful insights about the uplift history if other factors were secondary. Available proxy estimates based on marine boron-isotope (Pearson and Palmer, 2000), marine carbon isotope (Pagani et al., 1999, 2005) and paleobotanical evidence (Royer et al., 2001) consistently suggest a fall of the atmospheric $\mathrm{CO}_{2}$ level near the Oligocene/Miocene boundary, followed by rather stable $\mathrm{CO}_{2}$ levels during the Neogene. Whether these suggest an achieved state of major tectonic uplifts of global significance by that time is a worthy question to consider in the future, as it appears to be coherent with the results of paleo-altimetry approaches for the Tibetan region (DeCelles et al., 2006; Rowley and Currie, 2006; Rowley and Garzione, 2007). It should be noted, however, that proxy estimations of paleo- $\mathrm{CO}_{2}$ level may be biased by other factors (ex. Lemarchand et al., 2000). Also, the rather stable and near present-day levels of $\mathrm{CO}_{2}$ through the Neogene suggested by available estimates (Pagani et al., 1999, 2005; Perason and Palmer, 2000; Royer et al., 2001) face the question on explaining the ongoing global cooling since the early Neogene (Zachos et al., 2001).

\section{Conclusions}

Based on a significant amount of new data, we have examined the spatial distribution of environmental indicators in ten Paleogene-Neogene time intervals, as well as the properties of Miocene loess-soil sequences in northern China. The results led to the following conclusions.

1. Our geobiological data and map compilation confirm the earlier conclusion that the zonal climate pattern of the Paleogene was transformed into a monsoondominated pattern similar to the present-day one in the Neogene. These changes are marked by humidification in southwest and southeast China, disappearance of low-latitude aridity related to the subtropical highpressure zone, and emergence of inland deserts at higher latitudes. Detailed mapping within the Oligocene and Miocene indicates that the reorganization was achieved by the early Miocene, matching the time of onset of widespread loess deposition in northern China. Although the basal ages of the loess sections do not necessarily provide the earliest age of this major climate transition, other terrestrial and marine records tend to suggest an age near the Oligocene-Miocene boundary, at 25-22 Ma.

2. The dated Miocene loess-soil sections in northern China show spatially correlative stratigraphy and climate proxies, similar to younger eolian deposits in the region. 
The near-complete time coverage of Neogene and Pleistocene eolian deposits attest to the existence of inlands deserts in the Asian interior as persistent dust sources during the past $22 \mathrm{Ma}$ despite major changes of global climate. Spatial gradients of eolian grain-size indicate a source area lying north to the Loess Plateau in the inland deserts. They also provide evidence of strong dustcarrying circulation from the north in the Asian winter monsoon.

3. The well-developed Luvisols present since the early Miocene indicate the existence of a circulation of oceanic origin that brought moisture to northern China, in the Asian summer monsoons. The intensity of these circulations was significantly stronger than for the Quaternary. The accretionary properties of the soils attest to the presence of two seasonally alternating circulations, one from the oceans in the south carrying moisture and the other from the northern deserts carrying dust. These features rightly define a full monsoonal (seasonally reversing) climatic regime.

4. This major reorganization represents a fundamental transformation from a planetary circulation system to a monsoon-dominated system. Following this transition, the effects of the subtropical high-pressure zone in generating dry conditions at low latitudes weakened during the Neogene because of the strong influence of summer monsoons. In contrast, the effects of the winter Siberian High were reinforced. The roughly synchronous humidification in southwest and southeast China suggests a coupled strengthening of the southwest and southeast summer monsoon circulations, rather than largely diachronous developments. In confirming the roles of Tibetan uplift and Paratethys shrinkage as suggested in previous studies, our recent numerical experiments and new geological data suggest a combined effect of these two factors with a contribution from the spreading and opening of the South China Sea. The loess record provides a vital insight that these tectonic scenarios had evolved to a threshold by the early Miocene sufficient to cause this major climate change in Asia.

Acknowledgements. This work is supported by the National Project for Basic Research (2004CB720203), Chinese Academy of Sciences (Project KZCX2-YW-117) and National Natural Science Foundation of China (Project 40730104). Sincerest thanks are extended to William Ruddiman, Gille Ramstein, Denis Rousseau and an anonymous reviewer for the highly constructive reviews and suggestions.

Edited by: D.-D. Rousseau

\section{References}

Abe, M., Kitoh, A., and Yasunari, T.: An evolution of the Asian summer monsoon associated with mountain uplift - Simulation with the MRI atmosphere-ocean coupled GCM, J. Meteorol. Soc. Jpn., 81, 909-933, 2003.

Aitchison, J. C., Ali, J. R., and Davis, A. M.: When and where did India and Asia collide? J. Geophys. Res., 112, B05426, doi:1029/2006JB004706, 2007.

Akhmet'ev, M. A., Aleksandrova, G. N., Amon, E. O., Beniamovskii, V. N., Bugrova, E. M., Vasil'eva, O. N., Glezer, Z. I., Zhelezko, V. I., Zaporozhets, N. I., Kozlova, G. E., Nikolaeva, I. A., Oreshkina, T. V., Panova, L. A., Radionova, E. P., Strel'nikova, N. I., and Yakovleva, A. I.: Biostratigraphy of the marine Paleogene in the West Siberian plate, Stratigr. Geol. Correl., 9, 132-158, 2001.

Akhmet'ev, M. and Beniamovski, V.: The Paleocene and Eocene in the Russian Part of West Eurasia. Stratigr. Geol. Correl., 14, 49-72, 2006.

An, Z. S., Liu, T. S., Lu, Y. C., Porter, S. C., Kukla, G., Wu, X. H., and Hua, Y.: The long-term paleomonsoon variation recorded by the loess-paleosol sequence in Central China, Quatern. Int., 7, 91-96, 1990.

An, Z. S., Kutzbach, J. E., Prell, W. L., and Porter, S. C.: Evolution of Asian monsoons and phased uplift of the Himalaya-Tibetan plateau since Late Miocene times, Nature, 411, 62-66, 2001.

Berger, G. W.: Luminescence chronology of late Pleistocene loesspaleosol and tephra sequences near Fairbanks, Alaska, Quaternary Res., 60, 70-83, 2003.

Briais, A., Patriat, P., and Tapponnier, P.: Updated interpretation of magnetic-anomalies and sea-floor spreading stages in the South China Sea-implications for the Tertiary tectonics of SoutheastAsia, J. Geophys. Res., 98, 6299-6328, 1993.

Cande, S. C. and Kent, D. V.: Revised calibration of the geomagnetic polarity timescale for the Late Cretaceous and Cenozoic, J. Geophys. Res., 100, 6093-6095, 1995.

Cao, S. G. and He, Y. R.: Vertisols, in: Chinese Soil Taxonomy, edited by: Gong, Z. T., Science Press, Beijing, 261-323, 1999.

Chase, T. N., Knaff, J. A., Pielke, R. A., and Kalnay, E.: Changes in global monsoon circulations since 1950, Natural Hazards, 29, 229-254, 2003.

Chen, J., An, Z. S., Liu, L. W., Ji, J. F., Yang, J. D., and Chen, Y.: Variations in chemical compositions of the eolian dust in Chinese Loess Plateau over the past $2.5 \mathrm{Ma}$ and chemical weathering in the Asian inland, Sci. China Ser. D, 44, 403-413, 2001.

Chen, L. X., Zhu, Q. G., Luo, H. B., He, J. H., Dong, M., and Feng, Z. Q.: Monsoons Over East Asia (in Chinese), Meteorol. Publ., Beijing, 362 pp., 1991.

China Geological Survery. Chinese 1500000 Geological Map Database 1.0, 2001.

Chinese Stratum Thesaurus Editorial Board. Tertiary Stratum Thesaurus, 1999.

Chung, S. L., Hua, C., Lee, T. Y., Zhang, Y. Q., Xie, Y. W., Li, X. H., Wang, K. L., and Wang, P. L.: Dischronous uplift of the Tibetan Plateau starting 40 Myr ago, Nature, 394, 769-773, 1998.

Clark, M. K., House, M. A., Royden, L. H., Whipple, K. X., Burchfiel, B. C., Zhang, X. B., and Tang, W.: Late Cenozoic uplift of southeastern Tibet, Geology, 33, 525-528, 2005.

Clift, P. D.: Controls on the erosion of Cenozoic Asia and the flux of clastic sediment to the ocean, Earth and Planet. Sci. Lett., 241, 
571-580, 2006.

Coleman, M. and Hodges, K.: Evidence for Tibetan plateau uplift before $14 \mathrm{Myr}$ ago from a new minimum age for east-west extension, Nature, 374, 49-52, 1995

Corrigan, J. D. and Crowley, K. D.: Unroofing of the Himalayas-a view from apatite fission-track analysis of Bengal Fan sediments, Geophys. Res. Lett., 19, 2345-2348, 1992.

Cox, P. M., Harris, P. P., Huntingford, C., Betts, R.A., Collins, M., Jones, C.D., Jupp, T.E., Marengo, J.A., and Nobre, C.A.: Increasing risk of Amazonian drought due to decreasing aerosol pollution. Nature, 453, 212-215, 2008.

Cremaschi, M., Fedoroff, N., Guerreschi, A., Huxtable, J., Colombi, N., Castelletti, L., and Maspero, A.: Sedimentary and pedological processes in the Upper Pleistocene loess of northern Italy, The Bagaggera sequence, Quatern. Int., 5, 23-38, 1990.

DeCelles, P. G., Quade, J., Kapp, P., Fan, M. J., Dettman, D. L., and Ding, L.: High and dry in central Tibet during the Late Oligocene, Earth and Planet. Sci. Lett., 253, 389-401, 2007.

Derry, L. A. and France-Lanord, C.: Neogene growth of the sedimentary organic carbon reservoir, Paleoceanography, 11, 267275, 1996.

Dercourt, J., Ricou, L. E., and Vrielinck, B.: Atlas Tethys Paleoenvironmental Maps, Gauthier-Villars, Paris, 307 pp., 1993.

Ding, G. Y., Chen, J., Tian, Q. J., Shen, X. H., Xing, C. Q., and Wei, K. B.: Active faults and magnitudes of left-lateral displacement along the northern margin of the Tibetan Plateau, Tectonophysics, 380, 243-260, 2004.

Ding, L. and Zhong, D. L.: Metamorphic characteristics and geotectonic implications of the high-pressure granulites from Namjagbarwa, eastern Tibet, Sci. China Ser. D, 42, 491-505, 1999.

Ding, Z. L., Yu, Z. W., Rutter, N. W., and Liu, T. S.: Towards an orbital time-scale for Chinese loess deposits, Quaternary Sci. Rev., 13, 39-70, 1994.

Ding, Z. L., Liu, T. S., Rutter, N. W., Yu, Z. W., Guo, Z. T., and Zhu, R. X.: Ice-volume forcing of East Asian winter monsoon variations in the past 800000 years, Quaternary Res., 44, 149159,1995

Ding, Z. L., Sun, J. M., Liu, T. S., Zhu, R. X., Yang, S. L., and Guo, B.: Wind-blown origin of the Pliocene red clay formation in the central Loess Plateau, China, Earth and Planet. Sci. Lett., 161, 135-143, 1998

Duchaufour, P. H. : Pdologie, Tome I: Pdogense et Classification, Masson-Paris-New York-Barcelone-Milan, 477 pp., 1983.

FAO-Unesco: Soil Map of the World, 1:5000000 Vol. I, Legend, UNESCO, Paris, 20-32, 1974.

Fedoroff, N. and Goldberg, P.: Comparative micromorphology of two late Pleistocene paleosols (in the Paris Basin), Catena, 9, 227-251, 1982.

Flöhn, H.: Der indische sommermonsun als Glied der planetarischen Zirkulation der atmosphere, Bec. Des D. wd. Bd., 4, 22, 1956.

Fluteau, F., Ramstein, G., and Besse, J.: Simulating the evolution of the Asian and African monsoons during the past 30 Myr using an atmospheric general circulation model, J. Geophys. Res., 104, 11995-12018, 1999.

Fu, C. B.: Potential impacts of human-induced land cover change on East Asia monsoon, Global Planet. Change, 37, 219-229, 2003.

Garzione, C. N., Dettman, D. L., Quade, J., DeCelles, P. G., and
Butler, R. F.: High times on the Tibetan Plateau: Paleoelevation of the Thakkhola graben, Nepal, Geology, 28, 339-342, 2000.

Garzione, C. N., Ikari, M. J., and Basu, A. R.: Source of Oligocene to Pliocene sedimentary rocks in the Linxia basin in northeastern Tibet from Nd isotopes: Implications for tectonic forcing of climate, Geol. Soc. Am. Bull., 117, 1156-1166, 2005.

Gersonde, R., Crosta, X., Abelmann, A., and Armand, L.: Seasurface temperature and sea lee distribution of the Southern Ocean at the EPILOG Last Glacial Maximum - A circumAntarctic view based on siliceous microfossil records, Quat. Sci. Rev., 24, 869-896, doi:10.1016/j.quascirev.2004.07.015, 2005.

Ghosh, P., Adkins, J., Affek, H., Balta, B., Guo, W. F., Schauble, E. A., Schrag, D., and Eller, J. M.: ${ }^{13} \mathrm{C}-{ }^{18} \mathrm{O}$ bonds in carbonate minerals: A new kind of paleothermometer, Geochim. Cosmochim. Ac., 70, 1439-1456, 2006.

Guo, Z. F., Wilson, M., Liu, J. Q., and Mao, Q.: Post-collisional, potassic and ultrapotassic magmatism of the northern Tibetan Plateau: Constraints on characteristics of the mantle source, geodynamic setting and uplift mechanisms, J. Petrol., 47, 11771220, 2006.

Guo, Z. T., Fedoroff, N., An, Z. S., and Liu, T. S.: Interglacial dustfall and origin of iron oxides hydroxides in the paleosols of the Xifeng loess section, China, Sci. Geol. Sinica, 2, 91-100, 1993.

Guo, Z. T., Liu, T. S., Guiot, J., Wu, N. Q., L, H. Y., Han, J. M., Liu, J. Q., and $\mathrm{Gu}, \mathrm{Z}$. Y.: High frequency pulses of East Asian monsoon climate in the last two glaciations: link with the North Atlantic, Clim. Dynam., 12, 701-709, 1996.

Guo, Z. T., Fedoroff, N., and An, Z. S.: Genetic types of the Holocene soil and the Pleistocene palaeosols in the Xifeng loess section in central China, in: Loess, Environment and Global Change, edited by: Liu, T. S., Ding, Z. L., Guo, Z. T., Science Press, Beijing, 93-111, 1991.

Guo, Z. T., Liu, T. S., Fedoroff, N., Wei, L. Y., Ding, Z. L., Wu, N. Q., Lu, H. Y., Jiang, W. Y., and An, Z. S.: Climate extremes in loess of China coupled with the strength of deep-water formation in the North Atlantic, Global Planet. Change, 18, 113-128, 1998.

Guo, Z. T., Biscaye, P., Wei, L. Y., Chen, X. H., Peng, S. Z., and Liu, T. S.: Summer monsoon variations over the last $1.2 \mathrm{Ma}$ from the weathering of loess-soil sequences in China, Geophys. Res. Lett., 27, 1751-1754, 2000.

Guo, Z. T., Ruddiman, W. F., Hao, Q. Z., Wu, H. B., Qiao, Y. S., Zhu, R. X., Peng, S. Z., Wei, J. J., Yuan, B. Y., and Liu, T. S.: Onset of Asian desertification by $22 \mathrm{Myr}$ ago inferred from loess deposits in China, Nature, 416, 159-163, 2002.

Guo, Z. T.: Uplift of the Tibetan Plateau and the aeolian deposits in China (in Chinese), in: Formation of Tibetan Plateau, Environment and Development, edited by: Zheng, D. and Yao, T. D., Hebei Scientific and Technical Press, Shijiazhuang, 70-79, 2003.

Guo, Z. T., Peng, S. Z., Hao, Q. Z., Biscaye, P., An, Z. S., and Liu, T. S.: Late Miocene-Pliocene development of Asian aridification as recorded in the Red-Earth Formation in northern China, Global Planet. Change, 41, 135-145, 2004.

Halley, E.: An historical account of the trade winds and monsoons observable in the seas between and near the tropics with an attempt to assign the physical cause of the said wind, Philos.T. R Soc. Lond., 16, 153-168, 1986.

Hao, Q. Z. and Guo, Z. T.: Magnetostratigraphy of a late Miocene-Pliocene loess-soil sequence in the western 
Loess Plateau in China, Geophys. Res. Lett., 31, L09209, doi:10.1029/2003GL019392, 2004.

Hao, Q. Z. and Guo, Z. T.: Magnetostratigraphy of an early-middle Miocene loess-soil sequence in the western Loess Plateau of China, Geophys. Res. Lett., 34, L18305, doi:10.1029/2007GL031162, 2007.

Hao, Q.Z., Oldfield, F., Bloemendal, J., and Guo, Z.T.: The magnetic properties of loess and paleosol samples from the Chinese Loess Plateau spanning the last 22 million years, Palaeogeogr. Palaeocl., 260, 389-404, 2008.

Harrison, T. M., Copeland, P., Kidd, W. S. F., and Yin, A.: Raising Tibet, Science, 255, 1663-1670, 1992.

Harrison, T. M., Copeland, P., Hall, S. A., Quade, J., Burner, S., Ojha, T. P., and Kidd, W. S. F.: Isotopic preservation of Himalayan/Tibetan uplift, denudation, and climatic histories of two molasse deposits, J. Geol., 101, 157-175, 1993.

Hodell, D. A. and Woodruff, F.: Variations in the strontium isotopic ratio of seawater during the Miocene: Stratigraphic and geochemical implications, Paleoceanography, 9, 405-426, 1994.

Houghton, J. T.: The Global Climate, Cambridge University Press, Cambridge and New York, 239 pp., 1984.

Hovan, S. A. and Rea, D. K.: Post-Eocene record of eolian deposition at sites 752, 754, and 756, Eastern Indian Ocean, Proc. ODP Sci. Res, 121, 219-228, 1991.

Hussein, J. and Adey, M. A.: Changes in microstructure, voids and b-fabric of surface samples of a Vertisol caused by wet/dry cycles, Geoderma, 85, 63-82, 1998.

Iriondo, M.: Patagonian dust in Antarctica, Quat. Int., 68, 83-86, 2000.

Jahn, B. M., Gallet, S., and Han, J. M.: Geochemistry of the Xining, Xifeng and Jixian sections, Loess Plateau of China: eolian dust provenance and paleosol evolution during the last $140 \mathrm{ka}$, Chem. Geol., 178, 71-94, 2001.

Jia, G. D, Peng, P. A., Zhao, Q. H., and Jian, Z. M.: Changes in terrestrial ecosystem since $30 \mathrm{Ma}$ in East Asia: Stable isotope evidence from black carbon in the South China Sea, Geology, 31, 1093-1096, 2003.

Jiang, F. C., Wang, S. B., Zhao, Z. Z., and Fu, J. L.: Mangshan loess in Central China and the paleomonsoon variations since the last interglaciation, Acta Geol. Sin-Engl., 78, 813-819, 2004.

Johnson, W. C., Willey, K. L., Mason, J. A., and May, D. W.: Stratigraphy and environmental reconstruction at the middle Wisconsinan Gilman Canyon Formation type locality, Buzzard's Roost, southwestern Nebraska, USA, Quaternary Res., 67, 474486, 2007

Kemp, R. A.: Pedogenic modification of loess: significance for palaeoclimatic reconstructions, Earth-Sci. Rev., 54, 145-156, 2001.

Kroon, D., Steens, T., and Troelstra, S. R.: Onset of monsoonal related upwelling in the western Arabian Sea as revealed by planktonic foraminifers, Proc. ODP Sci. Res., 117, 257-263, 1991.

Kukla, G., An, Z. S., Melice, J. L., Gavin, J., and Xiao, J. L.: Magnetic susceptibility record of Chinese loess, T. Roy. Soc. EdinEarth., 81, 263-288, 1990.

Kutzbach, J. E., Guetter, P. J., Ruddiman, W. F., and Prell, W. L.: Sensitivity of climate to late Cenozoic uplift in Southern Asia and the American West: Numerical experiments, J. Geophys. Res., 94, 18 393-18 407, 1989.

Kutzbach, J. E., Prell, W. L., and Ruddiman, W. F.: Sensitivity of
Eurasian climate to surface uplift of the Tibetan Plateau, J. Geol., 101, 177-190, 1993.

Lambert, F., Delmonte, B., Petit, J. R., Bigler, M., Kaufmann, P. R., Hutterli, M. A., Stocker, T. F., Ruth, U., Steffensen, J. P., and Maggi, V.: Dust-climate couplings over the past 800000 years from the EPICA Dome C ice core. Nature, 452, 616-619, 2008.

Lear, C. H., Elderfield, H., and Wilson, P. A.: Cenozoic deepsea temperatures and global ice volumes from $\mathrm{Mg} / \mathrm{Ca}$ in benthic foraminiferal calcite, Science, 287, 269-272, 2000.

Lemarchand, D., Gaillardet, J., Lewin, E., and Allegre, C. J.: The influence of rivers on marine boron isotopes and implications for reconstructing past ocean $\mathrm{pH}$, Nature, 408, 951-954, 2000.

Lezine, A. M., Tiercelin, J. J., Robert, C., Saliege, J. F., Cleuziou, S., Inizan, M. L., and Braemer, F.: Centennial to millennial-scale variability of the Indian monsoon during the early Holocene from a sediment, pollen and isotope record from the desert of Yemen, Palaeogeogr., Palaeocl., 243, 235-249, 2007.

Li, F. J., Wu, N. Q., Pei, Y. P., Hao, Q. Z., and Rousseau, D. D.: Wind-blown origin of Dongwan late Miocene-Pliocene dust sequence documented by land snail record in western Chinese Loess Plateau, Geology, 34, 405-408, 2006 a.

Li, F. J., Wu, N. Q., and Rousseau, D. D.: Preliminary study of mollusk fossils in the Qinan Miocene loess-soil sequence in western Chinese Loess Plateau, Sci. China Ser. D, 49, 724-730, 2006 b.

Li, J. J. and Fang, X. M.: Uplift of the Tibetan Plateau and environmental changes, Chinese Sci. Bull., 44, 2117-2124, 1999.

Li, Q. Y., Han, Z. M., and Su, X.: Late Oligocene rapid transformations in the South China Sea, Mar. Micropaleontol., 54, 5-25, 2005.

Li, Q. Y., Wang, P. X., Zhao, Q. H., Shao, L., Zhong, G. F., Tian, J., Cheng, X. R., Han, Z. M., and Su, X.: A 33 Ma lithostratigraphic record of tectonic and paleoceanographic evolution of the South China Sea, Mar. Geol., 230, 217-235, 2006c.

Liang, M. Y., Guo, Z. T., and Gu, Z. Y.: Geochemical characteristics of the Miocene eolian deposits and comparison with those of the Pliocene and Quaternary eolian deposits (in Chinese with English abstract), Quaternary Science, 26, 657-664, 2006.

Liu, J. F., Guo, Z. T., Hao, Q. Z., Peng, S. Z., Qiao, Y. S., Sun, B., and Ge, J. Y.: Magnetostratigraphy of the Miziwan Miocene eolian deposits in Qin'an County (Gansu Province)(in Chinese with English abstract), Quaternary Science, 25, 503-508, 2005.

Liu, J. F., Guo, Z. T., Qiao, Y. S., Hao, Q. Z., and Yuan, B. Y.: Eolian origin of the Miocene loess-soil sequence at Qin'an, China: Evidence of quartz morphology and quartz grain-size, Chinese Sci. Bull., 51, 117-120, 2006.

Liu, T. S.: Loess and the Environment, China Ocean Press, Beijing, 251 pp., 1985.

Liu, T. S. and Guo, Z. T.: Geological environment in China and global change, in: Selected Works of Liu Tungsheng, edited by: An, Z. S., Science Press, Beijing, 192-202, 1997.

Liu, T. S. and Ding, Z. L.: Chinese loess and the paleomonsoon, Annu. Rev. Earth Pl. Sc., 26, 111-145, 1998.

Liu, X. D. and Yin, Z. Y.: Sensitivity of East Asian monsoon climate to the uplift of the Tibetan Plateau, Palaeogeogr. Palaeocl., 183, 223-245, 2002.

Lu, H. Y., Wang, S. M., Wu, N. Q., Tong, G. B., Yang, X. D., Shen, C. M., Li, S. J., Zhu, L. P., and Wang, L.: A new pollen record of the last 2.8 Ma from the Co Ngoin, central Tibetan Plateau, Sci. China Ser. D, 44, 292-300, 2001. 
Lu, H. Y., Wang, X. Y., An, Z. S., Miao, X. D., Zhu, R. X., Ma, H. Z., Li, Z., Tan, H. B., and Wang, X. Y.: Geomorphologic evidence of phased uplift of the northeastern Qinghai-Tibet Plateau since 14 million years ago, Sci. China Ser. D, 47, 822-833, 2004.

Markgraf, V., Baumgartner, T. R., Bradbury, J. P., Diaz, H. F., Dunbar, R. B., Luckman, B. H., Seltzer, G. O., Swetnam, T. W., and Villalba, R.: Paleoclimate reconstruction along the Pole-EquatorPole transect of the Americas (PEP 1), Quat. Sci. Rev., 19, 125140,2000

Manabe, S. and Terpstra, T. B.: The effects of mountains on the general circulation of the atmosphere as identified by numerical experiments, J. Atmos. Sci., 31, 3-42, 1974.

Meigs, P.: World distribution of arid and semi-arid homoclimates, in: UNESCO Arid Zone Research, Series No.1, Arid Zone Hydrology, UNESCO, Paris, 203-209, 1953.

Miao, X. D., Sun, Y. B., Lu, H. Y., and Mason, J. A.: Spatial pattern of grain size in the Late Pliocene 'Red Clay' deposits (North China) indicates transport by low-level northerly winds, Palaeogeogr. Palaeocl., 206, 149-155, 2004.

Miller, K. G., Faribanks, R. G., and Mountain, G. S.: Tertiary oxygen isotope synthesis, sealecel history, and continental margin erosion, Paleoceanography, 2, 1-19, 1987.

Miller, K. G., Mountain, G. S., Browning, J. V., Kominz, M., Sugarman, P. J., Christie-Blick, N., Katz, M. E., and Wright, J. D.: Cenozoic global sea level, sequences, and the New Jersey transect: Results from coastal plain and continental slope drilling, Rev. Geophys., 36, 569-601, 1998.

Molnar, P.: Mio-Pliocene growth of the Tibetan Plateau and evolution of Asian climate, Palaeontol. Electron., 8, 1-23, 2005.

Moran, K., Backman, J., Brinkhuis, H., Clemens, S. C., Cronin, T., Dickens, G. R., Eynaud, F., Gattacceca, J., Jakobsson, M., Jordan, R. W., Kaminski, M., King, J., Koc, N., Krylov, A., Martinez, N., Matthiessen, J., McInroy, D., Moore, T. C., Onodera, J., O’Regan, M., Palike, H., Rea, B., Rio, D., Sakamoto, T., Smith, D. C., Stein, R., St John, K., Suto, I., Suzuki, N., Takahashi, K., Watanabe, M., Yamamoto, M., Farrell, J., Frank, M., Kubik, P., Jokat, W., and Kristoffersen, Y.: The Cenozoic palaeoenvironment of the Arctic Ocean, Nature, 441, 601-605, 2006.

Pagani, M., Arthur, M. A., and Freeman, K. H.: Miocene evolution of atmospheric carbon dioxide, Paleoceanography, 14, 273-292, 1999.

Pagani, M., Zachos, J. C., Freeman, K. H., Tipple, B., and Bohaty, S.: Marked decline in atmospheric carbon dioxide concentrations during the Paleogene, Science, 309, 600-603, 2005.

Pavelic, D., Avanic, R., Bakrac, K., and Vrsaljko, D.: Early Miocene braided river and lacustrine sedimentation in the Kalnik Mountain area (Pannonian Basin System, NW Croatia), Geol. Carpath., 52, 375-386, 2001.

Pearson, P. N. and Palmer, M. R.: Atmospheric carbon dioxide concentrations over the past 60 million years, Nature, 406, 695-699, 2000.

Peng, S. Z. and Guo, Z. T.: Geochemical indicator of original eolian grain size and implications on winter monsoon evolution, Sci. China Ser. D, 44 (Suppl.), 261-266, 2001.

Porter, S. C.: Chinese loess record of monsoon climate during the last glacial-interglacial cycle, Earth-Sci. Rev., 54, 115-128, 2001.

Prell, W. L. and Kutzbach, J. E.: Sensitivity of the Indian monsoon to forcing parameters and implications for its evolution, Nature,
360, 647-652, 1992.

Pye, K.: The nature, origin and accumulation of loess, Quaternary Sci. Rev., 14, 653-667, 1995.

Qiao, Y. S., Guo, Z. T., Hao, Q. Z., Wu, W. X., Jiang, W. Y., Yuan, B. Y., Zhang, Z. S., Wei, J. J., and Zhao, H.: Loess-soil sequences in southern Anhui Province: Magnetostratigraphy and paleoclimatic significance, Chinese Sci. Bull., 48, 2088-2093, 2003.

Qiao, Y. S., Guo, Z. T., Hao, Q. Z., Yin, Q. Z., Yuan, B. Y., and Liu, T. S.: Grain-size features of a Miocene loess-soil sequence at Qinan: Implications on its origin, Sci. China Ser. D, 49, 731738, 2006.

Qiu, Z. D. and Li, C. K.: Evolution of Chinese mammalian faunal regions and elevation of the Qinghai-Xizang (Tibet) Plateau, Sci China Ser. D, 48, 1246-1258, 2005.

Quade, J., Cerling, T. E., and Bowman, J. R.: Development of Asian monsoon revealed by marked ecological shift during the latest Miocene in northern Pakistan, Nature, 342, 163-166, 1989.

Ramstein, G., Fluteau, F., Besse, J., and Joussaume, S.: Effect of orogeny, plate motion and land-sea distribution on Eurasian climate change over the past 30 million years, Nature, 386, 788795, 1997.

Raymo, M. E. and Ruddiman, W. F.: Tectonic forcing of Late Cenozoic climate, Nature, 359, 117-122., 1992.

Raymo, M. E., Ruddiman, W. F., and Froelich, P. N.: Influence of late Cenozoic mountain building on ocean geochemical cycles, Geology, 16, 649-653, 1988.

Rea, D. K., Leinen, M., and Janecek, T. R.: Geologic approach to the long-term history of atmospheric circulation, Science, 227, 721-725, 1985.

Rea, D. K.: The paleoclimatic record provided by eolian deposition in the deep-sea - the geologic history of wind, Rev. Geophys., 32, 159-195, 1994.

Rousseau, D. D. and Kukla, G.: Late Pleistocene climate record in the Eustis loess section, Nebraska, based on land snail assemblages and magnetic susceptibility, Quaternary Res., 42, 176187, 1994.

Rousseau, D. D., Kukla, G., Zoller, L., and Hradilova, J.: Early Weichselian dust storm layer at Achenheim in Alsace, France, Boreas, 27, 200-207, 1998.

Rowley, D. B. and Currie, B. S.: Palaeo-altimetry of the late Eocene to Miocene Lunpola basin, central Tibet, Nature, 439, 677-681, 2006.

Rowley, D. B., and Garzione, C. N.: Stable isotope-based paleoaltimetry, Annu. Rev. Earth. Pl. Sc., 35, 463-508, 2007.

Royer, D. L., Wing, S. L., Beerling, D. J., Jolley, D. W., Koch, P. L., Hickey, L. J., and Berner, R. A.: Paleobotanical evidence for near present-day levels of atmospheric $\mathrm{CO}_{2}$ during part of the tertiary, Science, 292, 2310-2313, 2001.

Ruddiman, W.F., Raymo, M.E., Prell, W.L., and Kutzbach, J.: The uplift-climate connection: a synthesis, in: Tectonic uplift and climate change, edited by Ruddiman, W.F., Plenum Press, New York and London, 471-515, 1997.

Ruddiman, W. F. and Kutzbach, J. E.: Forcing of late Cenozoic Northern Hemisphere climate by plateau uplift in southern Asia and the American West, J. Geophys. Res., 94, 18 409-18 427, 1989.

Ruddiman, W. F., Prell, W. L., and Raymo, M. E.: Late Cenozoic uplift in southern Asia and the American West: rational for general circulation modeling experiments, J. Geophys. Res., 94, 
18 379-18391, 1989.

Shi, Y. F., Tang, M. C., and Ma, Y. Z.: Linkage between the second uplifting of the Qinghai-Xizang (Tibetan) Plateau and the initiation of the Asian monsoon system, Sci. China Ser. D, 42, 303-312, 1999.

Song, Z. C., Li, H. M., Zheng, Y. H., and Liu, G.: Miocene floristic region of China (in Chinese), in: Palaeobiogeographic Provinces of China, edited by: Lu, Y. H., Beijing Science Press, Beijing, 178-184, 1983.

Spicer, R. A., Harris, N. B. W., Widdowson, M., Herman, A. B., Guo, S., Valdes, P. J., Wolfek, J. A., and Kelley, S. P.: Constant elevation of southern Tibet over the past 15 million years, Nature, 412, 622-624, 2003.

Stuut, J. B. W., and Lamy, F.: Climate variability at the southern boundaries of the Namib (Southwestern Africa) and Atacama (northern Chile) coastal deserts during the last $120000 \mathrm{yr}$, Quat. Res., 62, 301-309, doi:10.1016/j.yqres.2004.08.001, 2004.

Sun, D. H., Liu, T. S., Chen, M. Y., An, Z. S., and Shaw, J.: Magnetostratigraphy and palaeoclimate of Red Clay sequences from Chinese Loess Plateau, Sci. China Ser. D, 40, 337-343, 1997.

Sun, J. M.: Provenance of loess material and formation of loess deposits on the Chinese Loess Plateau, Earth and Planet. Sci. Lett., 203, 845-859, 2002.

Sun, X. J. and Wang, P. X.: How old is the Asian monsoon system?Palaeobotanical records from China, Palaeogeogr., Palaeocl., 222, 181-222, 2005.

Taylor, S. R., McLennan, S. M., and McCulloch, M. T.: Geochemistry of loess, continental crustal composition and crustal model ages, Geochim. Cosmochim. Ac., 47, 1897-1905, 1983.

Tsoar, H. and Pye, K.: Dust transport and the question of desert loess formation, Sedimentology, 34, 139-153, 1987.

Turner, S., Hawkesworth, C., Liu, J. Q., Rogers, N., Kelley, S., and Vancalsteren, P.: Timing of Tibetan Uplift Constrained by Analysis of Volcanic-Rocks, Nature, 364, 50-54, 1993.

Valdiya, K. S.: Rising Himalaya: Advent and intensification of monsoon, Curr. Sci. India, 76, 514-524, 1999.

Wang, B.: The Asian Monsoon, Springer, UK, 844 pp., 2006.

Wang, C. S., Zhao, X. X., Liu, Z. F., Lippert, P. C., Graham, S. A., Coe, R. S., Yi, H. S., Zhu, L. D., Liu, S., and Li, Y. L.: Constraints on the early uplift history of the Tibetan Plateau, P. Natl. Acad. Sci. USA, 105, 4987-4992, 2008.

Wang, J., Wang, Y. J., Liu, Z. C., Li, J. Q., and Xi, P.: Cenozoic environmental evolution of the Qaidam Basin and its implications for the uplift of the Tibetan Plateau and the drying of central Asia, Palaeogeogr. Palaeocl., 152, 37-47, 1999.

Wang, P. X.: Neogene stratigraphy and paleoenvironments of China, Palaeogeogr. Palaeocl., 77, 315-324, 1990.

Xiao, J. L., Porter, S. C., An, Z. S., Kumai, H., and Yoshikawa, S.: Grain-Size of Quartz as an Indicator of Winter Monsoon Strength on the Loess Plateau of Central China during the Last 130000 Yr, Quaternary Res., 43, 22-29, 1995.
Yuan, B. Y., Guo, Z. T., Hao, Q. Z., Peng, S. Z., Qiao, Y. S., Wu, H. B., Xiao, G. Q., Ge, J. Y., Sun, B., Zhou, X., Yin, Q. Z., Liang, M. Y., Qin, L., Liu, L., Yao, Z. Q., and Liu, T. S.: Cenozoic evolution of geomorphic and sedimentary environments in the TianshuiQin'an regions (in Chinese with English abstract), Quaternary Science, 27, 161-171, 2007.

Zachos, J., Pagani, M., Sloan, L., Thomas, E., and Billups, K.: Trends, rhythms, and aberrations in global climate $65 \mathrm{Ma}$ to present, Science, 292, 686-693, 2001.

Zachos, J., Breza, J. R., and Wise, S. W.: Early Oligocene icesheet expansion on Antarctica: Stable isotope and sedimentological evidence from Kerguelen Plateau, southern Indian Ocean, Geology, 20, 569-573, 1992.

Zhang, J. M., Xiao, D. N., Huang, R. J., and Zhang, F. R.: Luvisols, in: Chinese Soil Taxonomy, edited by: Gong, Z. T., Science Press, Beijing, 537-607, 1999.

Zhang, Z. K., He, H. C., Li, S. H., Tian, H. T., and Wang, Y.: The discovery of Miocene aeolian sediments and its paleoenvironmental significance in East China (in Chinese with English abstract), Acta Sedimentologica Sinica, 25, 116-123, 2007.

Zhang, Z. S. and Guo, Z. T.: Spatial reconstructions of paleoenvironments for different periods in the Oligocene and Miocene (in Chinese with English abstract), Quaternary Science, 25, 523530, 2005.

Zhang, Z. S., Wang, H. J., Guo, Z. T., and Jiang, D. B.: Impact of topography and land-sea distribution on East Asian paleoenvironmental patterns, Adv. Atmos. Sci., 23, 258-266, 2006.

Zhang, Z. S., Wang, H. J., Guo, Z. T., and Jiang, D. B.: What triggers the transition of palaeoenvironmental patterns in China, the Tibetan Plateau uplift or the Paratethys Sea retreat?, Palaeogeogr. Palaeocl., 245, 317-331, 2007a.

Zhang, Z. S., Wang, H. J., Guo, Z. T., and Jiang, D. B.: Impacts of tectonic changes on the reorganization of the Cenozoic paleoclimatic patterns in China, Earth and Planet. Sci. Lett., 257, 622-634, 2007b.

Zhao, Q. H.: Microfossils from loess of the Miaodao Islands, Bohai Sea, Sci. China Ser. D, 26, 445-451, 1996.

Zheng, H. B., Powell, C. M., An, Z. S., Zhou, J., and Dong, G. R.: Pliocene uplift of the northern Tibetan Plateau, Geology, 28, 715-718, 2000.

Ziegler, C. L., Murray, R. W., Hovan, S. A., and Rea, D. K.: Resolving eolian, volcanogenic, and authigenic components in pelagic sediment from the Pacific Ocean, Earth and Planet. Sci. Lett., 254, 416-432, 2007.

Zoller, L., Rousseau, D. D., Jager, K. D., and Kukla, G.: Last interglacial, Lower and Middle Weichselian - a comparative study from the Upper Rhine and Thuringian Loess areas, Z. Geomorphol., 48, 1-24, 2004. 